Jaroszyńska Zuzanna, Andrusiewicz Mirosław, Wiśniewska Katarzyna. Knowledge and attitudes of Czaplinek Municipality residents with regard to colorectal cancer prevention. Journal of Education, Health and Sport. 2022;12(1):65-91. eISSN 2391-8306. DOI http://dx.doi.org/10.12775/JEHS.2022.12.01.006

https://apcz.umk.pl/JEHS/article/view/JEHS.2022.12.01.006

https://zenodo.org/record/5841957

The journal has had 40 points in Ministry of Education and Science of Poland parametric evaluation. Annex to the announcement of the Minister of Education and Science of December 1, 2021. No. 32343. Has a Journal's Unique Identifier: 201159. Scientific disciplines assigned: Physical Culture Sciences (Field of Medical sciences and health sciences); Health Sciences (Field of Medical Sciences and Health Sciences).

Punkty Ministerialne z 2019 - aktualny rok 40 punktów. Zalącznik do komunikatu Ministra Edukacji i Nauki z dnia 1 grudnia 2021 r. Lp. 32343. Posiada Unikatowy Identyfikator Czasopisma: 201159. Przypisane dyscypliny naukowe: Nauki o kulturze fizycznej (Dziedzina nauk medycznych i nauk o zdrowiu); Nauki o zdrowiu (Dziedzina nauk medycznych i nauk o zdrowiu).

(c) The Authors 2022;

This article is published with open access at Licensee Open Journal Systems of Nicolaus Copernicus University in Torun, Poland

Open Access. This article is distributed under the terms of the Creative Commons Attribution Noncommercial License which permits any noncommercial use, distribution, and reproduction in any medium,

provided the original author (s) and source are credited. This is an open access article licensed under the terms of the Creative Commons Attribution Non commercial license Share alike. The authors declare that there is no conflict of interests regarding the publication of this paper.

Received: 15.12.2021. Revised: 25.12.2021. Accepted: 12.01.2022.

\title{
Wiedza i postawy mieszkańców gminy Czaplinek w zakresie profilaktyki raka jelita grubego
}

Knowledge and attitudes of Czaplinek Municipality residents with regard to colorectal cancer prevention

\section{Zuzanna Jaroszyńska}

E-mail address: zu.jaroszynska@gmail.com

ORCID iD: https://orcid.org/0000-0003-2349-179X

Affiliation: Public Health graduate - Poznan University of Medical Sciences, Poznan, Poland

\section{Mirosław Andrusiewicz}

E-mail address: andrus@ump.edu.pl

ORCID iD: https://orcid.org/0000-0002-8781-3447

Affiliation: Chair and Department of Cell Biology, Epigenetic Unit, Poznan University of Medical Sciences, Poznan, Poland

\section{Katarzyna Wiśniewska}

E-mail address: kwisniewska@ump.edu.pl

ORCID iD: https://orcid.org/0000-0003-0025-1398

Affiliation: Department of Preventive Medicine, Epidemiology Unit, Poznan University of Medical Sciences, Poznan, Poland

\section{Streszczenie}

Wprowadzenie i cel: Rak jelita grubego (C18-C21) stanowi obecnie w Polsce drugą wśród mężczyzn i trzecią wśród kobiet przyczynę zgonów nowotworowych. Celem pracy była ocena wiedzy oraz postaw mieszkańców gminy Czaplinek w zakresie profilaktyki raka jelita grubego.

Material i metoda: Badanie przeprowadzono w okresie od października do grudnia 2020 roku wśród 238 mieszkańców gminy Czaplinek, położonej w województwie zachodniopomorskim, w powiecie drawskim. Narzędzie badawcze stanowił autorski kwestionariusz ankiety, składający się z 22 pytań o charakterze zamkniętym. Otrzymane wyniki opracowano $\mathrm{w}$ arkuszu kalkulacyjnym Microsoft $^{\circledR}$ Excel $^{\circledR} 2016$ MSO i poddano analizie statystycznej przy użyciu oprogramowania Statistica ${ }^{\circledR}$ (TIBCO Software Inc.).

Wyniki: Przeważająca część ankietowanych $(74,8 \%)$ wiedziała, że wczesne zdiagnozowanie raka jelita grubego znacząco zwiększa szanse na jego wyleczenie. Tylko połowa respondentów $(50,8 \%)$ miała świadomość tego, że nowotwór ten może rozwijać się bezobjawowo. Znajomość czynników ryzyka oraz objawów raka jelita grubego w grupie 
badanej była niska. Ogólny poziom wiedzy respondentów na temat raka jelita grubego i jego profilaktyki był najczęściej dostateczny $(62,5 \%)$. Niespełna jedna trzecia ankietowanych (31,5\%) słyszała o Programie Badań Przesiewowych raka jelita grubego.

Wnioski: Poziom wiedzy oraz postaw mieszkańców gminy Czaplinek w zakresie raka jelita grubego i jego profilaktyki jest zdecydowanie niezadowalający. Istnieje pilna potrzeba prowadzenia intensywnych działań edukacyjnych, skupiających się przede wszystkim na promowaniu badań przesiewowych w kierunku raka jelita grubego.

Słowa kluczowe: rak jelita grubego; wiedza; postawy; profilaktyka; zdrowie publiczne

\begin{abstract}
Introduction and purpose: Colorectal cancer $(\mathrm{C} 18-\mathrm{C} 21)$ is currently the second cause of cancer-related deaths among men and the third among women in Poland. The aim of the paper was to assess the knowledge and attitudes of the Czaplinek Municipality residents with regard to colorectal cancer prevention.
\end{abstract}

Material and Method: The research was conducted between October and December 2020 among 238 inhabitants of the Czaplinek Municipality, located in Zachodniopomorskie Voivodeship, Drawsko District. The research tool was an original survey questionnaire, consisting of 22 closed-ended questions. The results obtained were processed in a Microsoft ${ }^{\circledR}$ Excel $^{\circledR} 2016$ MSO spreadsheet and statistically analysed using Statistica ${ }^{\circledR}$ software (TIBCO Software Inc.).

Results: The majority of the respondents $(74.8 \%)$ knew that early diagnosis of colorectal cancer significantly increases the chances of recovery. Only half of the respondents $(50.8 \%)$ were aware that this cancer can develop asymptomatically. Knowledge of risk factors and symptoms of colorectal cancer in the study group was low. The respondents' overall level of knowledge about colorectal cancer and its prevention was most often sufficient (62.5\%). Less than a third of the respondents $(31.5 \%)$ had heard of the Colorectal Cancer Screening Programme.

Conclusions: The level of knowledge and attitudes of the Czaplinek Municipality inhabitants regarding colorectal cancer and its prevention is definitely unsatisfactory. There is an urgent need for intensive educational activities, focusing primarily on promoting colorectal cancer screening.

Key words: colorectal cancer; knowledge; attitudes; prevention; public health

\title{
Wprowadzenie
}

Rak jelita grubego, traktowany jako nowotwór złośliwy, występujący w obrębie okrężnicy, zgięcia esiczo-odbytniczego, odbytnicy i odbytu (C18-C21) stanowi poważny problem zdrowotny polskiej populacji. W 2018 roku w Polsce nowotwór ten był trzecim wśród mężczyzn i drugim wśród kobiet najczęściej rozpoznawanym nowotworem złośliwym. Liczba odnotowanych w 2018 roku w Polsce zgonów z powodu nowotworów złośliwych jelita grubego wyniosła niemal 12,5 tys. Czyniło to wówczas raka jelita grubego drugą najczęstszą przyczyną zgonów nowotworowych mężczyzn oraz trzecią najczęstszą przyczyną zgonów z powodu nowotworów złośliwych wśród kobiet [1-4]. Nowotwory złośliwe jelita grubego w Polsce nadal często rozpoznawane są zbyt późno, co zmniejsza szanse na skuteczne leczenie, powodując tym samym obniżenie wskaźników przeżywalności chorych [5-12].

Poprawa sytuacji zdrowotnej współczesnego społeczeństwa w zakresie raka jelita grubego, prowadząca do zmniejszenia współczynników zachorowalności i umieralności, a także do zwiększenia wskaźników przeżywalności chorych możliwa jest poprzez wdrożenie 
działań z zakresu pierwotnej i wtórnej profilaktyki tego nowotworu złośliwego w skali populacyjnej $[8,11,12]$.

Profilaktyka pierwotna obejmuje działania mające na celu zapobieganie wystąpieniu choroby poprzez eliminację lub ograniczenie ekspozycji na czynniki sprzyjające jej rozwojowi. Do modyfikowalnych czynników ryzyka raka jelita grubego należą głównie dieta oraz styl życia, dlatego to właśnie one odgrywają najistotniejszą rolę w profilaktyce pierwotnej tego schorzenia $[13,14]$.

Celem profilaktyki wtórnej raka jelita grubego jest rozpoznanie zmian przednowotworowych lub choroby nowotworowej zanim wystąpią objawy kliniczne, mogące wskazywać na jej rozwój. Pozwala to na podjęcie interwencji terapeutycznej jeszcze przed rozwojem nowotworu złośliwego lub we wczesnym stadium jego zaawansowania - wówczas, gdy szanse na skuteczne leczenie są największe $[13,15]$. Kluczowym elementem profilaktyki wtórnej raka jelita grubego są badania przesiewowe (skriningowe), jednak istnieje wiele metod diagnostycznych, pozwalających na rozpoznanie nieprawidłowości w obrębie jelita grubego $[5,7,13]$.

Kolonoskopia jest badaniem, charakteryzującym się największą czułością i swoistością w rozpoznawaniu zmian przednowotworowych i nowotworów złośliwych jelita grubego we wczesnym stadium [16,17]. Sprawia to, że jest ona uznawana obecnie za złoty standard w diagnostyce raka jelita grubego, stanowiąc tym samym najbardziej wartościowe badanie skriningowe $[5,8,15,16,18,19]$. Optymalną metodą przesiewową w raku jelita grubego, dla osób o przeciętnym ryzyku zachorowania, bez objawów, mogących świadczyć o rozwoju procesu nowotworowego, jest kolonoskopia wykonywana co 10 lat, począwszy od 50 roku życia [13,19,20,21,22]. Szacuje się, iż wykonywanie profilaktycznej kolonoskopii, dzięki której możliwe jest wczesne wykrycie i usunięcie zmian przednowotworowych, może przyczynić się do zmniejszenia ryzyka zachorowania na raka jelita grubego o 60-90\% [5,8,21].

Obecnie w Polsce, w ramach Narodowej Strategii Onkologicznej na lata 2020-2030 (NSO) realizowany jest Program Badań Przesiewowych raka jelita grubego (PBP) [23,24]. Program finansowany jest przez Ministerstwo Zdrowia, a jego Koordynatorem jest Narodowy Instytut Onkologii im. Marii Skłodowskiej-Curie - Państwowy Instytut Badawczy [13,23,24]. Program obejmuje wykonywanie bezpłatnych profilaktycznych badań kolonoskopowych u osób, które ze względu na wiek lub obciążony wywiad rodzinny obarczone są zwiększonym ryzykiem zachorowania [23,24].

Program Badań Przesiewowych raka jelita grubego realizowany jest w Polsce od 2000 roku. Do końca 2011 roku Program miał charakter wyłącznie oportunistyczny - kandydaci do badań zgłaszali się samodzielnie do wyznaczonych ośrodków lub byli kierowani do nich przez lekarzy POZ. Od 2012 roku, z powodu niekorzystnych wskaźników epidemiologicznych oraz zgodnie $\mathrm{z}$ najnowszymi zaleceniami europejskimi, PBP przekształcany jest stopniowo w program populacyjny (zapraszany), w ramach którego do adresatów Programu wysyłane są także jednokrotnie imienne zaproszenia na bezpłatne przesiewowe badania kolonoskopowe. Zaproszenia zawierają proponowaną datę i godzinę badania w wyznaczonym ośrodku realizującym PBP. Skrining raka jelita grubego w Polsce funkcjonuje zatem obecnie $w$ dwóch trybach: oportunistycznym i populacyjnym (zapraszanym) [5,13,19,20,23,24].

Warunkiem skuteczności programów skriningowych jest objęcie badaniami profilaktycznymi jak największego odsetka populacji docelowej $[6,13,20]$. W pierwszym roku realizacji Programu Badań Przesiewowych raka jelita grubego, liczba ośrodków biorących udział w Programie wynosiła 11, natomiast w 2017 roku kolonoskopię w ramach PBP wykonywało 118 placówek (90 w systemie oportunistycznym i $28 \mathrm{w}$ trybie populacyjnym).

Od początku realizacji Programu do końca 2017 roku przeprowadzono w Polsce ponad 500 000 bezpłatnych przesiewowych badań kolonoskopowych (w systemach oportunistycznym i 
populacyjnym łącznie). Jednak mimo, iż zasięg terytorialny Programu oraz liczba wykonywanych kolonoskopii zwiększa się na przestrzeni lat, poziom zgłaszalności na badania przesiewowe w kierunku raka jelita grubego jest zatrważająco niski. W pierwszym roku funkcjonowania programu populacyjnego, zaproszenie na skriningową kolonoskopię otrzymało 23145 osób, jednak pozytywnie odpowiedziało tylko 3918 pacjentów. Oznacza to, że w 2012 roku zgłaszalność na badania kolonoskopowe w trybie zapraszanym wyniosła 16,9\%. W 2017 roku zaproszenie na bezpłatną kolonoskopię wysłano do 325247 adresatów Programu. Z możliwości wykonania badania skorzystało 41868 osób, w wyniku czego wskaźnik zgłaszalności na badania kolonoskopowe w trybie populacyjnym (zapraszanym) w 2017 roku wyniósł zaledwie 12,9\% [25].

Przyczyn aktualnej sytuacji epidemiologicznej raka jelita grubego w Polsce można upatrywać m. in. w niewystarczającej świadomości społecznej dotyczącej profilaktyki onkologicznej. Konieczne jest zatem wdrożenie kompleksowych działań, prowadzących do wykształcenia odpowiednich postaw prozdrowotnych w populacji. Warunkiem jednak ich skuteczności jest precyzyjna identyfikacja obszarów wymagających zmian, a także rozpoznanie czynników determinujących poszczególne zjawiska z nimi związane.

\section{Cel}

Celem pracy była ocena wiedzy oraz postaw mieszkańców gminy Czaplinek w zakresie profilaktyki raka jelita grubego.

\section{Material i metoda}

Analizą objęto 238 osób zamieszkujących teren gminy Czaplinek, położonej w województwie zachodniopomorskim, w powiecie drawskim.

Badanie zostało przeprowadzone w okresie od października do grudnia 2020 roku. Materiał badawczy zebrano metodą sondażu diagnostycznego, w ramach którego posłużono się autorskim kwestionariuszem ankiety, skonstruowanym $\mathrm{w}$ oparciu o przegląd aktualnego piśmiennictwa. Zawierał on 22 pytania o charakterze zamkniętym, z czego pierwsze 7 dotyczyło danych socjodemograficznych (płeć, wiek, miejsce zamieszkania, stan cywilny, wykształcenie), zachorowania na raka jelita grubego oraz występowania tych nowotworów w rodzinie. Pytania 8-17 miały na celu weryfikację wiedzy ankietowanych na temat raka jelita grubego oraz działań $\mathrm{z}$ zakresu prewencji pierwotnej i wtórnej, z kolei pytania 18-22 dotyczyły postaw wobec profilaktyki tej grupy nowotworów. W pytaniach 8-11, 18, 19 i 21 istniała możliwość zaznaczenia więcej niż jednej odpowiedzi (kafeteria koniunktywna).

W kwestionariuszu ankiety, którym posłużono się w badaniu, wśród proponowanych odpowiedzi zawarto także odpowiedzi nieprawidłowe.

Badanie było anonimowe, udział $\mathrm{w}$ nim był dobrowolny, wszyscy respondenci wyrazili świadomą zgodę na udział $\mathrm{w}$ badaniu oraz zostali poinformowani o celu jego prowadzenia.

Oceny wiedzy respondentów na temat raka jelita grubego i jego profilaktyki dokonano na podstawie punktacji odpowiedzi udzielonych w pytaniach 8-17. Zarówno w pytaniach jednokrotnego (kafeteria dysjunktywna), jak i wielokrotnego wyboru (kafeteria koniunktywna), za udzielenie poprawnej odpowiedzi respondentom przyznawano 1 punkt, zaś za wskazanie odpowiedzi błędnej lub odpowiedzi: „nie wiem” - odejmowano go. Uzyskane przez respondentów punkty zsumowano, a następnie przyporządkowano je do jednego z czterech przedziałów punktowych, oznaczających odpowiednio: niedostateczny, dostateczny, dobry lub bardzo dobry poziom wiedzy.

Otrzymane wyniki opracowano w arkuszu kalkulacyjnym Microsoft ${ }^{\circledR}$ Excel $^{\circledR} 2016$ MSO i poddano analizie statystycznej przy użyciu oprogramowania Statistica ${ }^{\circledR}$ w wersji 13.3.721.0 (TIBCO Software Inc.). Analizę statystyczną przeprowadzono z uwzględnieniem wpływu takich zmiennych, jak: płeć, wiek, miejsce zamieszkania, wykształcenie oraz rodzinne występowanie nowotworów jelita grubego. Szczegółowej analizie poddano ilość 
zaklasyfikowanych do odpowiednich przedziałów punktów, uzyskanych przez respondentów łącznie w pytaniach 8-17. Z uwagi na jakościowy charakter analizowanych zmiennych

w opracowaniu posłużono się testami nieparametrycznymi. Do weryfikacji istotności statystycznej różnic $\mathrm{w}$ rozkładzie liczby punktów między badanymi grupami zastosowano test U Manna-Whitneya dla porównania dwóch grup, natomiast dla porównania trzech lub więcej grup - test Kruskala-Wallisa. W przypadku odnotowania istotnego statystycznie wyniku testu Kruskala-Wallisa przeprowadzano test post-hoc (porównań wielokrotnych) Dunna.

Wartości $p$ testów statystycznych przedstawiano $\mathrm{z}$ dokładnością do części dziesięciotysięcznych (zaokrąglano do czterech miejsc po przecinku). Przy wnioskowaniu statystycznym przyjęto poziom istotności testów $\alpha=0,05$, co pozwoliło uznać za istotne zmienne przy $p<0,05$.

\section{Wyniki}

\section{Charakterystyka grupy badanej}

Szczegółową charakterystykę grupy 238 objętych badaniem respondentów przedstawiono w tabeli 1.

Tabela 1. Charakterystyka grupy badanej

\begin{tabular}{|c|c|c|c|}
\hline \multicolumn{2}{|l|}{ Zmienne } & Liczba badanych $(n)$ & $\begin{array}{c}\text { Odsetek grupy } \\
\text { badanej (\%) }\end{array}$ \\
\hline \multirow{2}{*}{ Płeć } & Kobiety & 187 & 78,6 \\
\hline & Mężczyźni & 51 & 21,4 \\
\hline \multicolumn{2}{|l|}{ Razem } & 238 & 100,0 \\
\hline \multirow{3}{*}{ Wiek } & Poniżej 50 lat & 184 & 77,3 \\
\hline & 50-65 lat & 39 & 16,4 \\
\hline & Powyżej 65 lat & 15 & 6,3 \\
\hline \multicolumn{2}{|l|}{ Razem } & 238 & 100,0 \\
\hline \multirow{2}{*}{ Miejsce zamieszkania } & Miasto & 171 & 71,8 \\
\hline & Wieś & 67 & 28,2 \\
\hline \multicolumn{2}{|l|}{ Razem } & 238 & 100,0 \\
\hline \multirow{4}{*}{ Stan cywilny } & Panna/kawaler & 89 & 37,4 \\
\hline & Zamężna/żonaty & 126 & 52,9 \\
\hline & Po rozwodzie & 13 & 5,5 \\
\hline & Wdowa/wdowiec & 10 & 4,2 \\
\hline \multicolumn{2}{|l|}{ Razem } & 238 & 100,0 \\
\hline \multirow{5}{*}{ Wykształcenie } & Podstawowe/gimnazjalne & 28 & 11,8 \\
\hline & Zasadnicze zawodowe & 38 & 16,0 \\
\hline & Średnie & 66 & 27,7 \\
\hline & Policealne & 16 & 6,7 \\
\hline & Wyższe & 90 & 37,8 \\
\hline \multicolumn{2}{|l|}{ Razem } & 238 & 100,0 \\
\hline \multirow{2}{*}{$\begin{array}{c}\text { Występowanie raka jelita grubego } \\
\text { u respondentów }\end{array}$} & Tak & 3 & 1,3 \\
\hline & Nie & 235 & 98,7 \\
\hline \multicolumn{2}{|l|}{ Razem } & 238 & 100,0 \\
\hline \multirow{3}{*}{$\begin{array}{l}\text { Rodzinne obciqżenie nowotworami jelita } \\
\text { grubego }\end{array}$} & Tak & 34 & 14,3 \\
\hline & Nie & 165 & 69,3 \\
\hline & Nie wiem & 39 & 16,4 \\
\hline Razem & & 238 & 100,0 \\
\hline
\end{tabular}

\section{Wiedza mieszkańców gminy Czaplinek na temat raka jelita grubego i jego profilaktyki}

Przeważająca część ankietowanych $(74,8 \%, \mathrm{n}=178)$ wiedziała, że wczesne zdiagnozowanie raka jelita grubego znacząco zwiększa szanse na jego wyleczenie. Ryzyko zachorowania na raka jelita grubego wzrasta wraz $\mathrm{z}$ wiekiem według 57,6\% grupy objętej analizą ( $\mathrm{n}=137)$, a świadomość tego, że nowotwór ten może rozwijać się bezobjawowo miała połowa respondentów $(50,8 \%, \mathrm{n}=121)$. Zdanie mówiące o tym, iż rak jelita grubego występuje częściej u mężczyzn niż u kobiet zostało uznane za zgodne z prawdą przez 39,5\% ankietowanych $(\mathrm{n}=94)$, a wiedzę na temat tego, że nowotwór ten rozpoznawany jest 
najczęściej u osób po 50 roku życia miało $37,4 \%$ respondentów $(n=89)$. Tylko co czwarta ankietowana osoba $(22,3 \%, \mathrm{n}=53)$ wiedziała, że większość zgonów z powodu raka jelita grubego obserwowana jest wśród osób po 60 roku życia, a o tym, że nowotwór ten jest drugą najczęstszą przyczyną zgonów $\mathrm{z}$ powodu nowotworów złośliwych $\mathrm{w}$ populacji polskich mężczyzn wiedziało $21 \%$ respondentów $(\mathrm{n}=50)$. Świadomość tego, że ryzyko zgonu $\mathrm{z}$ powodu

raka jelita grubego jest najwyższe u osób, które ukończyły 80 rok życia miało zaledwie 13\% ankietowanych $(n=31)$. Tylko $12,2 \%$ badanych $(n=29)$ wiedziało, że rak jelita grubego jest drugim najczęściej występującym nowotworem złośliwym w żeńskiej populacji Polski, a 7 respondentów $(2,9 \%)$ błędnie uznało za prawdziwe twierdzenie, iż młodzi ludzie chorują na raka jelita grubego częściej niż osoby starsze.

W pytaniu polegającym na dokonaniu oceny prawdziwości twierdzeń na temat raka jelita grubego respondenci mogli uzyskać od -1 do 9 punktów. Najwyższy odsetek badanej grupy stanowili ankietowani, których wiedza na temat podstawowych epidemiologicznych i klinicznych danych dotyczących raka jelita grubego była dostateczna $(56,7 \%, n=135)$.

Co czwarta ankietowana osoba $(23,9 \%, n=57)$ wykazała się dobrą wiedzą w tym zakresie, $\mathrm{z}$ kolei $18,1 \%$ respondentów $(n=43)$ na podstawie udzielonych odpowiedzi na to pytanie uzyskało ocenę niedostateczną. Zaledwie 3 ankietowane osoby (1,3\%) wykazały się bardzo dobrą wiedzą w tym zakresie, uzyskując od 8 do 9 punktów (ryc. 1).

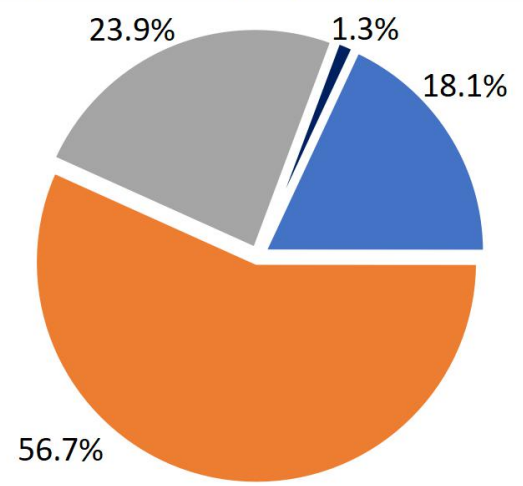

niedostateczna (od -1 do 1 pkt)

dostateczna (od 2 do 4 pkt)

dobra (od 5 do 7 pkt)

- bardzo dobra (od 8 do 9 pkt)

Rycina 1. Ocena wiedzy respondentów na temat podstawowych epidemiologicznych i klinicznych danych dotyczących raka jelita grubego

Do najczęściej wskazywanych przez ankietowanych czynników predysponujących do wystąpienia raka jelita grubego należały: nadwaga lub otyłość $(61,3 \%, n=146)$, niska aktywność fizyczna $(55,5 \%, n=132)$, stany zapalne jelit $(49,6 \%, n=118)$, uwarunkowania genetyczne $(49,6 \%, n=118)$, dieta uboga $\mathrm{w}$ błonnik $(47,1 \%, \mathrm{n}=112)$, palenie tytoniu $(46,6 \%$, $\mathrm{n}=111)$ oraz nadmierne spożywanie alkoholu $(45,8 \%, \mathrm{n}=109)$. Z kolei wśród najrzadziej wskazywanych przez respondentów czynników ryzyka rozwoju raka jelita grubego znalazły się: zakażenie HIV, zakażenie HPV, posiadanie kilku partnerów seksualnych $(8 \%, \mathrm{n}=19)$, przebyta cholecystektomia $(5,5 \%, n=13)$ oraz niski poziom HDL we krwi $(5 \%, n=12)$.

Pytanie dotyczące czynników zwiększających prawdopodobieństwo wystąpienia raka jelita grubego umożliwiło respondentom uzyskanie od 0 do 23 punktów. Niemal połowa badanych $(45 \%, \mathrm{n}=107)$ posiadała niedostateczną wiedzę $\mathrm{w}$ tym zakresie, wskazując co najwyżej 5 spośród 23 wymienionych czynników sprzyjających rozwojowi raka jelita grubego, a 40,3\% respondentów ( $n=96)$ posiadało dostateczną wiedzę na ten temat. Zaledwie co dziesiąta ankietowana osoba $(10,5 \%, n=25)$ wykazała się dobrą znajomością czynników ryzyka rozwoju raka jelita grubego, natomiast wiedzę na bardzo dobrym poziomie $\mathrm{w}$ tym zakresie posiadało tylko 10 objętych badaniem respondentów (4,2\%) (ryc. 2). 


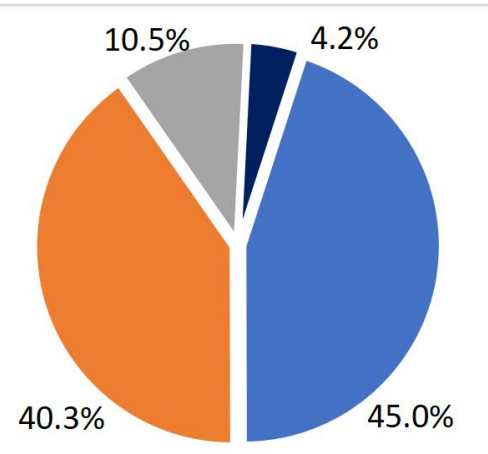

$$
\begin{aligned}
& \text { niedostateczna (od } 0 \text { do } 5 \text { pkt) } \\
& \text { dostateczna (od } 6 \text { do } 11 \text { pkt) } \\
& \text { dobra (od } 12 \text { do } 17 \text { pkt) } \\
& \text { - bardzo dobra (od } 18 \text { do } 23 \text { pkt) }
\end{aligned}
$$

Rycina 2. Ocena wiedzy respondentów na temat czynników ryzyka rozwoju raka jelita grubego

Wśród najczęściej wskazywanych przez respondentów objawów, mogących świadczyć o rozwoju raka jelita grubego znalazły się: krwawienie podczas wypróżniania $(75,2 \%, n=179)$, obecność krwi w/na stolcu $(62,2 \%, n=148)$, ból brzucha, krocza i/lub odbytu $(49,2 \%, n=117)$, spadek masy ciała i/lub ogólne osłabienie organizmu $(47,9 \%, n=114)$, a także zaparcia $(39,9 \%, n=95)$ i widoczny lub wyczuwalny guz $\mathrm{w}$ okolicy odbytu $(34,5 \%$, $\mathrm{n}=82$ ). Do najrzadziej zaś identyfikowanych przez ankietowanych objawów raka jelita grubego należały: wąskie „ołówkowate” stolce $(19,3 \%, \mathrm{n}=46)$, nietrzymanie stolca $\mathrm{i} / \mathrm{lub}$ gazów $(18,9 \%, n=45)$, dyskomfort podczas siedzenia $(17,2 \%, n=41)$ i świąd okolicy odbytu $(15,1 \%, n=36)$.

Skala, w jakiej dokonano oceny wiedzy respondentów na temat objawów raka jelita grubego zawierała się w przedziale od 0 do 16 punktów. Najwyższy odsetek grupy objętej analizą stanowiły osoby, których poziom wiedzy w tym zakresie był dostateczny $(42,9 \%$, $\mathrm{n}=102)$, natomiast ponad jedna trzecia ankietowanych $(35,7 \%, \mathrm{n}=85)$ posiadała niedostateczną wiedzę na ten temat, identyfikując co najwyżej 3 z 16 możliwych do zaznaczenia symptomów, mogących świadczyć o rozwoju raka jelita grubego. Dobrą znajomością objawów

raka jelita grubego wykazała się co ósma ankietowana osoba $(12,6 \%, n=30)$, z kolei bardzo dobrą - zaledwie 21 respondentów (8,8\%) (ryc. 3).

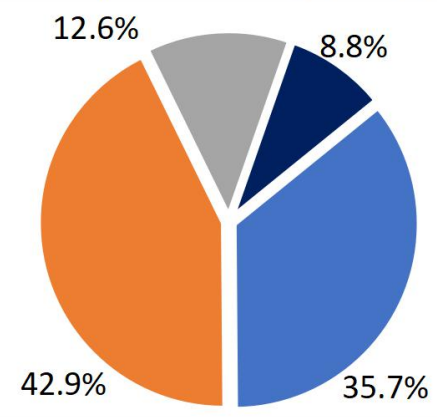

$$
\begin{aligned}
& \text { niedostateczna (od } 0 \text { do } 3 \text { pkt) } \\
& \text { dostateczna (od } 4 \text { do } 7 \text { pkt) } \\
& \text { dobra (od } 8 \text { do } 11 \text { pkt) } \\
& \text { - bardzo dobra (od } 12 \text { do } 16 \text { pkt) }
\end{aligned}
$$

Rycina 3. Ocena wiedzy respondentów na temat objawów raka jelita grubego

Do działań z zakresu profilaktyki pierwotnej raka jelita grubego respondenci zaliczyli przede wszystkim regularną aktywność fizyczną $(68,9 \%, \mathrm{n}=164)$, stosowanie diety bogatej $\mathrm{w}$ błonnik pokarmowy, warzywa, owoce i ryby $(66,4 \%, n=158)$ oraz utrzymywanie prawidłowej masy ciała $(61,8 \%, n=147)$. Korzystne działanie ograniczenia spożywania alkoholu oraz niepalenia tytoniu zostało wskazane przez nieco ponad połowę ankietowanych (odpowiednio: $58,4 \%(\mathrm{n}=139)$ i $52,9 \%(\mathrm{n}=126)$ respondentów), natomiast ograniczenie spożycia czerwonego mięsa wskazało $39,1 \%$ badanych $(\mathrm{n}=93)$.

Działania, które mogłyby zapobiec zachorowaniu na raka jelita grubego, jednak ich stosowanie nie jest zalecane, tj. długotrwałe przyjmowanie niesteroidowych leków przeciwzapalnych, w tym kwasu acetylosalicylowego oraz stosowanie hormonalnej terapii zastępczej $\mathrm{u}$ kobiet $\mathrm{w}$ okresie pomenopauzalnym zostało zaliczone do działań profilaktycznych przez odpowiednio $15,5 \%(n=37)$ i $10,1 \%(n=24)$ badanych. 
W pytaniu dotyczącym działań zapobiegających zachorowaniu na raka jelita grubego respondenci mogli uzyskać od 0 do 8 punktów. Co trzecia ankietowana osoba $(29,8 \%, n=71)$ posiadała niedostateczną wiedzę $\mathrm{w}$ tym zakresie, identyfikując co najwyżej $2 \mathrm{z} 8$ wymienionych działań, mogących przyczynić się do zmniejszenia ryzyka rozwoju raka jelita grubego. Dostateczną wiedzę na ten temat posiadała nieco ponad jedna trzecia badanych $(34,5 \%, n=82)$, dobrą $-29 \%$ respondentów $(n=69)$, z kolei bardzo dobrą znajomością działań, mogących zapobiec zachorowaniu na raka jelita grubego wykazało się tylko 16 ankietowanych osób $(6,7 \%)$ (ryc. 4).

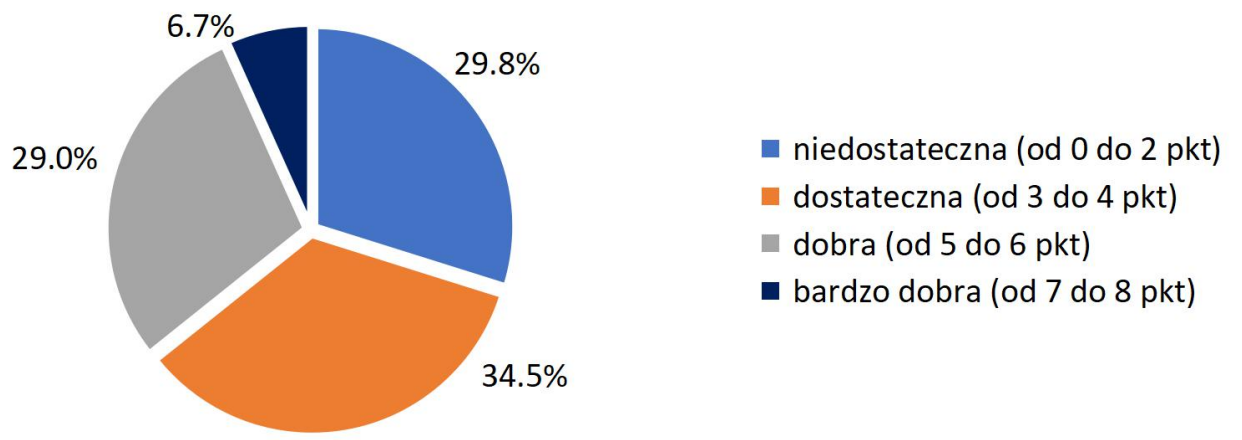

Rycina 4. Ocena wiedzy respondentów na temat działań zapobiegających zachorowaniu na raka jelita grubego

Spośród ogółu respondentów, $155(65,1 \%)$ wiedziało, że badania przesiewowe (skriningowe) to badania profilaktyczne, wykonywane $\mathrm{w}$ celu rozpoznania choroby $\mathrm{w}$ początkowym, jeszcze bezobjawowym jej stadium, obejmujące najczęściej osoby, które posiadają podwyższone ryzyko zachorowania na daną chorobę. Większość ankietowanych $(63,9 \%, n=152)$ była świadoma tego, że zalecanym i stosowanym najczęściej w celu wczesnego wykrycia raka jelita grubego badaniem profilaktycznym jest kolonoskopia. Wiek, w jakim należy rozpocząć wykonywanie badań profilaktycznych w kierunku raka jelita grubego znany był niespełna jednej trzeciej grupy objętej analizą $(31,9 \%, n=76)$. Tylko 31,5\% respondentów $(\mathrm{n}=75)$ poprawnie wskazało zalecaną częstość wykonywania badania na obecność krwi utajonej w kale. Większość respondentów $(79,8 \%, n=190)$ wiedziała, na czym polega badanie kolonoskopowe. Tylko 31,5\% $(n=75)$ grupy badanej słyszało o Programie Badań Przesiewowych raka jelita grubego. Spośród 75 ankietowanych, którzy słyszeli o Programie Badań Przesiewowych raka jelita grubego, większość $(68 \%, n=51)$ wiedziała, do kogo jest on skierowany. Zaledwie 18,7\% respondentów, którzy słyszeli o Programie Badań Przesiewowych raka jelita grubego $(n=14)$ wiedziało, że $\mathrm{z}$ bezpłatnych badań kolonoskopowych wykonywanych w ramach Programu w przypadku przeciętnego ryzyka zachorowania na raka jelita grubego można korzystać co 10 lat (tab. 2).

Tabela 2. Wiedza respondentów na temat raka jelita grubego i jego profilaktyki (pytania jednokrotnego wyboru)

\begin{tabular}{|c|c|c|c|}
\hline \multicolumn{2}{|l|}{ Zmienne } & Liczba badanych $(n)$ & $\begin{array}{c}\text { Odsetek grupy } \\
\text { badanej (\%) }\end{array}$ \\
\hline \multirow{2}{*}{ Znajomość definicji badań przesiewowych } & Tak & 155 & 65,1 \\
\hline & Nie & 83 & 34,9 \\
\hline \multicolumn{2}{|l|}{ Razem } & 238 & 100,0 \\
\hline \multirow{2}{*}{$\begin{array}{l}\text { Wiedza na temat zalecanego i stosowanego najczęściej w celu } \\
\text { wykrycia raka jelita grubego badania profilaktycznego }\end{array}$} & Tak & 152 & 63,9 \\
\hline & $\mathrm{Nie}$ & 86 & 36,1 \\
\hline \multicolumn{2}{|l|}{ Razem } & 238 & 100,0 \\
\hline \multirow{2}{*}{$\begin{array}{l}\text { Wiedza na temat wieku, w jakim należy rozpoczqć wykonywanie } \\
\text { badań profilaktycznych w kierunku raka jelita grubego }\end{array}$} & Tak & 76 & 31,9 \\
\hline & Nie & 162 & 68,1 \\
\hline \multicolumn{2}{|l|}{ Razem } & 238 & 100,0 \\
\hline
\end{tabular}




\begin{tabular}{|c|c|c|c|}
\hline \multirow{2}{*}{$\begin{array}{l}\text { Wiedza na temat zalecanej częstości wykonywania badania na } \\
\text { obecność krwi utajonej w kale }\end{array}$} & Tak & 75 & 31,5 \\
\hline & Nie & 163 & 68,5 \\
\hline \multicolumn{2}{|l|}{ Razem } & 238 & 100,0 \\
\hline \multirow{2}{*}{ Wiedza na temat badania kolonoskopowego } & Tak & 190 & 79,8 \\
\hline & Nie & 48 & 20,2 \\
\hline \multicolumn{2}{|l|}{ Razem } & 238 & 100,0 \\
\hline \multirow{2}{*}{ Znajomość Programu Badań Przesiewowych raka jelita grubego } & Tak & 75 & 31,5 \\
\hline & Nie & 163 & 68,5 \\
\hline \multicolumn{2}{|l|}{ Razem } & 238 & 100,0 \\
\hline \multirow{2}{*}{$\begin{array}{c}\text { Wiedza na temat adresatów Programu Badań Przesiewowych } \\
\text { raka jelita grubego (wśród } 75 \text { respondentów, którzy słyszeli o } \\
\text { Programie) }\end{array}$} & Tak & 51 & 68,0 \\
\hline & $\mathrm{Nie}$ & 24 & 32,0 \\
\hline \multicolumn{2}{|l|}{ Razem } & 75 & 100,0 \\
\hline \multirow{2}{*}{$\begin{array}{c}\text { Wiedza na temat tego, jak często można korzystać z bezpłatnych } \\
\text { badań kolonoskopowych wykonywanych w ramach Programu } \\
\text { Badań Przesiewowych raka jelita grubego w przypadku } \\
\text { przeciętnego ryzyka zachorowania (wśród } 75 \text { respondentów, } \\
\text { którzy słyszeli o Programie) }\end{array}$} & Tak & 14 & 18,7 \\
\hline & $\mathrm{Nie}$ & 61 & 81,3 \\
\hline \multicolumn{2}{|l|}{ Razem } & 75 & 100,0 \\
\hline
\end{tabular}

Pytania weryfikujące wiedzę na temat raka jelita grubego $\mathrm{i}$ jego profilaktyki umożliwiły ankietowanym uzyskanie łącznie od -9 do 64 punktów. Niemal dwie trzecie respondentów $(62,5 \%, \mathrm{n}=149)$ posiadało dostateczny poziom wiedzy na temat raka jelita grubego $i$ jego profilaktyki, natomiast co piąta ankietowana osoba $(18,1 \%, n=43)$ posiadała niedostateczną wiedzę w tym zakresie, uzyskując łącznie zaledwie od -9 do 9 punktów. Dobry poziom wiedzy na temat raka jelita grubego i jego profilaktyki posiadał co szósty respondent $(16 \%, n=38)$, z kolei bardzo dobrą wiedzą wykazało się tylko 8 ankietowanych $(3,4 \%)$ (ryc. $5)$.

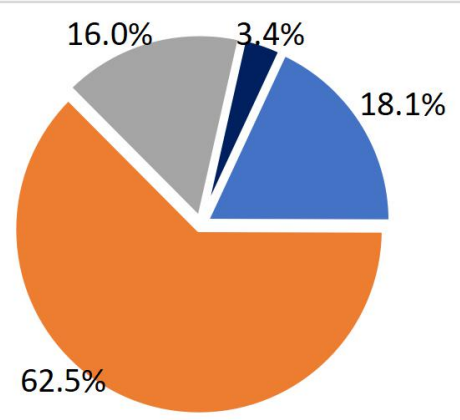

niedostateczna (od -9 do 9 pkt)
dostateczna (od 10 do 28 pkt)
dobra (od 29 do 47 pkt)
- bardzo dobra (od 48 do 64 pkt)

Rycina 5. Ocena ogólnej wiedzy respondentów na temat raka jelita grubego i jego profilaktyki

Nie wykazano znamiennego związku między ogólnym poziomem wiedzy na temat raka jelita grubego i jego profilaktyki a: płcią $(p=0,0856)$, wiekiem $(p=0,8614)$ oraz miejscem zamieszkania respondentów $(p=0,4419)$.

Odnotowano istotne statystycznie zależności między ogólnym poziomem wiedzy na temat raka jelita grubego i jego profilaktyki a wykształceniem respondentów. Wynik testu Kruskala-Wallisa: $p=0,0146$. Najwyższym ogólnym poziomem wiedzy wykazali się respondenci $\mathrm{z}$ wyższym wykształceniem. Test porównań wielokrotnych wskazał, iż ankietowani $\mathrm{z}$ wykształceniem wyższym wykazali się znamiennie większą ogólną znajomością zagadnień związanych $\mathrm{z}$ rakiem jelita grubego $\mathrm{i}$ jego profilaktyką niż respondenci z wykształceniem zasadniczym zawodowym. Wynik testu U Manna-Whitneya (porównującego te dwie grupy): $p=0,0038$.

Ogólny poziom wiedzy różnił się także znamiennie w zależności od występowania nowotworów jelita grubego wśród krewnych ankietowanych. Wynik testu Kruskala-Wallisa: $p=0,0024$. Najwyższym ogólnym poziomem wiedzy wykazali się ankietowani potwierdzający 
rodzinne obciążenie nowotworami jelita grubego. Na podstawie analizy wyników testu porównań wielokrotnych wykazano, iż poziom wiedzy zaprezentowany przez tę grupę różnił się istotnie statystycznie od wiedzy zaprezentowanej przez respondentów, którzy zadeklarowali brak wiedzy na temat występowania przypadków zachorowań w rodzinie $(p=0,0101)$ (tab. 3).

Tabela 3. Ocena ogólnej wiedzy respondentów na temat raka jelita grubego i jego profilaktyki według danych socjodemograficznych

\begin{tabular}{|c|c|c|c|c|c|c|c|}
\hline \multirow{2}{*}{\multicolumn{3}{|c|}{ Zmienne }} & \multicolumn{4}{|c|}{ Ocena ogólnej wiedzy respondentów } & \multirow{3}{*}{$\begin{array}{l}\underset{\mathcal{E}}{\mathcal{N}} \\
\stackrel{\mathbb{N}}{\simeq} \\
\\
187\end{array}$} \\
\hline & & & 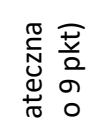 & 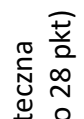 & $\begin{array}{r}\frac{F}{a} \\
\frac{f}{2}\end{array}$ & 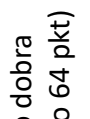 & \\
\hline \multirow{4}{*}{ Płeć } & \multirow{2}{*}{ Kobiety } & $\mathrm{n}$ & 30 & 118 & 32 & 7 & \\
\hline & & $\%$ & 16,0 & 63,2 & 17,1 & 3,7 & 100,0 \\
\hline & \multirow{2}{*}{ Mężczyźni } & $\mathrm{n}$ & 13 & 31 & 6 & 1 & 51 \\
\hline & & $\%$ & 25,5 & 60,7 & 11,8 & 2,0 & 100,0 \\
\hline \multicolumn{3}{|c|}{ wartość $p$ - test U Manna-Whitneya } & \multicolumn{4}{|c|}{$p=0,0856$} & \\
\hline \multirow{6}{*}{ Wiek } & \multirow{2}{*}{ Poniżej 50 lat } & $\mathrm{n}$ & 34 & 114 & 29 & 7 & 184 \\
\hline & & $\%$ & 18,5 & 61,9 & 15,8 & 3,8 & 100,0 \\
\hline & \multirow{2}{*}{$50-65$ lat } & $\mathrm{n}$ & 5 & 27 & 7 & 0 & 39 \\
\hline & & $\%$ & 12,8 & 69,3 & 17,9 & 0,0 & 100,0 \\
\hline & \multirow{2}{*}{ Powyżej 65 lat } & $\mathrm{n}$ & 4 & 8 & 2 & 1 & 15 \\
\hline & & $\%$ & 26,7 & 53,3 & 13,3 & 6,7 & 100,0 \\
\hline \multicolumn{3}{|c|}{ wartość $p$ - test Kruskala-Wallisa } & \multicolumn{4}{|c|}{$p=0,8614$} & \\
\hline \multirow{4}{*}{ Miejsce zamieszkania } & \multirow{2}{*}{ Miasto } & $\mathrm{n}$ & 33 & 106 & 27 & 5 & 171 \\
\hline & & $\%$ & 19,3 & 62,0 & 15,8 & 2,9 & 100,0 \\
\hline & \multirow{2}{*}{ Wieś } & $\mathrm{n}$ & 10 & 43 & 11 & 3 & 67 \\
\hline & & $\%$ & 14,9 & 64,2 & 16,4 & 4,5 & 100,0 \\
\hline \multicolumn{3}{|c|}{ wartość $p$ - test U Manna-Whitneya } & \multicolumn{4}{|c|}{$p=0,4419$} & \\
\hline \multirow{10}{*}{ Wykształcenie } & \multirow{2}{*}{ Podstawowe/gimnazjalne } & $\mathrm{n}$ & 10 & 11 & 4 & 3 & 28 \\
\hline & & $\%$ & 35,7 & 39,3 & 14,3 & 10,7 & 100,0 \\
\hline & \multirow{2}{*}{ Zasadnicze zawodowe } & $\mathrm{n}$ & 11 & 22 & 4 & 1 & 38 \\
\hline & & $\%$ & 28,9 & 58,0 & 10,5 & 2,6 & 100,0 \\
\hline & \multirow{2}{*}{ Średnie } & $\mathrm{n}$ & 11 & 48 & 7 & 0 & 66 \\
\hline & & $\%$ & 16,7 & 72,7 & 10,6 & 0,0 & 100,0 \\
\hline & \multirow{2}{*}{ Policealne } & $\mathrm{n}$ & 4 & 9 & 3 & 0 & 16 \\
\hline & & $\%$ & 25,0 & 56,2 & 18,8 & 0,0 & 100,0 \\
\hline & \multirow{2}{*}{ Wyższe } & $\mathrm{n}$ & 7 & 59 & 20 & 4 & 90 \\
\hline & & $\%$ & 7,8 & 65,6 & 22,2 & 4,4 & 100,0 \\
\hline \multicolumn{3}{|c|}{ wartość $p$ - test Kruskala-Wallisa } & & & & & \\
\hline & Tak & $\mathrm{n}$ & 1 & 24 & 8 & 1 & 34 \\
\hline & Tan & $\%$ & 2,9 & 70,7 & 23,5 & 2,9 & 100,0 \\
\hline Rodzinne obciq̨żenie & Nie & $\mathrm{n}$ & 30 & 100 & 28 & 7 & 165 \\
\hline nowotworami jelita grubego & mic & $\%$ & 18,2 & 60,6 & 17,0 & 4,2 & 100,0 \\
\hline & Nie wiem & $\mathrm{n}$ & 12 & 25 & 2 & 0 & 39 \\
\hline & TVie viemil & $\%$ & 30,8 & 64,1 & 5,1 & 0,0 & 100,0 \\
\hline wartość $p-t$ & t Kruskala-Wallisa & & & & & & \\
\hline
\end{tabular}

\section{Postawy mieszkańców gminy Czaplinek wobec profilaktyki raka jelita grubego}

Zdecydowana większość respondentów powyżej 50 roku życia $(90,7 \%, n=49)$ nigdy nie skorzystała $\mathrm{z}$ możliwości wykonania bezpłatnego badania kolonoskopowego w ramach Programu Badań Przesiewowych raka jelita grubego (tab. 4), a najczęściej wskazywaną tego 
przyczyną był brak wiedzy o takiej możliwości $(57,1 \%, \mathrm{n}=28)$. Dla 19 respondentów $(38,8 \%)$ powodem nieskorzystania $\mathrm{z}$ bezpłatnego badania kolonoskopowego $\mathrm{w}$ ramach Programu był ograniczony dostęp do badań diagnostycznych na zamieszkiwanym obszarze, natomiast według 12 ankietowanych problemem była krępująca forma badania $(24,5 \%)$, a także lęk przed bólem, mogącym pojawić się podczas jego wykonywania $(24,5 \%)$. W opinii 6 respondentów powodem nieskorzystania $\mathrm{z}$ bezpłatnego badania kolonoskopowego w ramach Programu był lęk przed zdiagnozowaniem choroby $(12,2 \%)$ oraz brak zaufania do specjalistów $(12,2 \%)$.

Tabela 4. Korzystanie $\mathrm{z}$ bezpłatnych badań kolonoskopowych $\mathrm{w}$ ramach Programu Badań Przesiewowych raka jelita grubego (wśród 54 respondentów powyżej 50 roku życia)

\begin{tabular}{|c|c|c|c|}
\hline \multicolumn{2}{|l|}{ Zmienne } & Liczba badanych (n) & $\begin{array}{c}\text { Odsetek grupy } \\
\text { badanej (\%) }\end{array}$ \\
\hline \multirow{2}{*}{$\begin{array}{l}\text { Korzystanie z bezpłatnych badań kolonoskopowych w ramach } \\
\text { Programu Badań Przesiewowych raka jelita grubego } \\
\text { (wśród } 54 \text { respondentów powyżej } 50 \text { roku życia) }\end{array}$} & Tak & 5 & 9,3 \\
\hline & $\mathrm{Nie}$ & 49 & 90,7 \\
\hline \multicolumn{2}{|l|}{ Razem } & 54 & 100,0 \\
\hline
\end{tabular}

Zamiar zgłoszenia się na bezpłatne przesiewowe badanie kolonoskopowe wyraziła zaledwie co czwarta ankietowana osoba powyżej 50 roku życia, która nigdy wcześniej nie skorzystała z możliwości wykonania bezpłatnego badania kolonoskopowego w ramach Programu Badań Przesiewowych raka jelita grubego (26,5\%, n=13) (tab. 5).

Tabela 5. Zamiar zgłoszenia się na bezpłatne przesiewowe badanie kolonoskopowe wśród 49 respondentów powyżej 50 roku życia, którzy nigdy nie skorzystali z możliwości wykonania bezpłatnego badania kolonoskopowego w ramach Programu Badań Przesiewowych raka jelita grubego

\begin{tabular}{|c|c|c|c|}
\hline Zmienne & & Liczba badanych $(n)$ & $\begin{array}{c}\text { Odsetek grupy } \\
\text { badanej (\%) }\end{array}$ \\
\hline \multirow{2}{*}{$\begin{array}{c}\text { Zamiar zgłoszenia się na bezpłatne przesiewowe badanie } \\
\text { kolonoskopowe wśród } 49 \text { respondentów powyżej } 50 \text { roku } \\
\text { życia, którzy nigdy nie skorzystali z możliwości wykonania } \\
\text { bezpłatnego badania kolonoskopowego w ramach Programu } \\
\text { Badań Przesiewowych raka jelita grubego }\end{array}$} & Tak & 13 & 26,5 \\
\hline & $\mathrm{Nie}$ & 36 & 73,5 \\
\hline Razem & & 49 & 100,0 \\
\hline
\end{tabular}

Spośród ogółu respondentów, niemal trzy czwarte $(72,7 \%, n=173)$ zadeklarowało, że nigdy nie poddało się żadnemu z 7 wymienionych badań profilaktycznych w kierunku raka jelita grubego. Badanie kolonoskopowe zrealizowało kiedykolwiek tylko 17,6\% ankietowanych $(n=42)$, test na obecność krwi utajonej w kale $-6,3 \%$ respondentów $(n=15), z$ kolei badania genetyczne $\mathrm{w}$ kierunku predyspozycji do wystąpienia raka jelita grubego zostały wykonane u 4,6\% respondentów $(n=11)$. Oznaczanie stężenia antygenu rakowo płodowego (CEA - ang. carcinoembryonic antigen) w surowicy krwi w przeszłości zadeklarowało 8 ankietowanych osób $(3,4 \%)$, a rektoskopię wykonano kiedykolwiek u 7 respondentów (2,9\%). Sigmoidoskopii (1,7\%) lub badaniu proktologicznemu (per rectum) $(1,7 \%)$ w przeszłości poddało się łącznie zaledwie 8 ankietowanych osób (ryc. 6). 


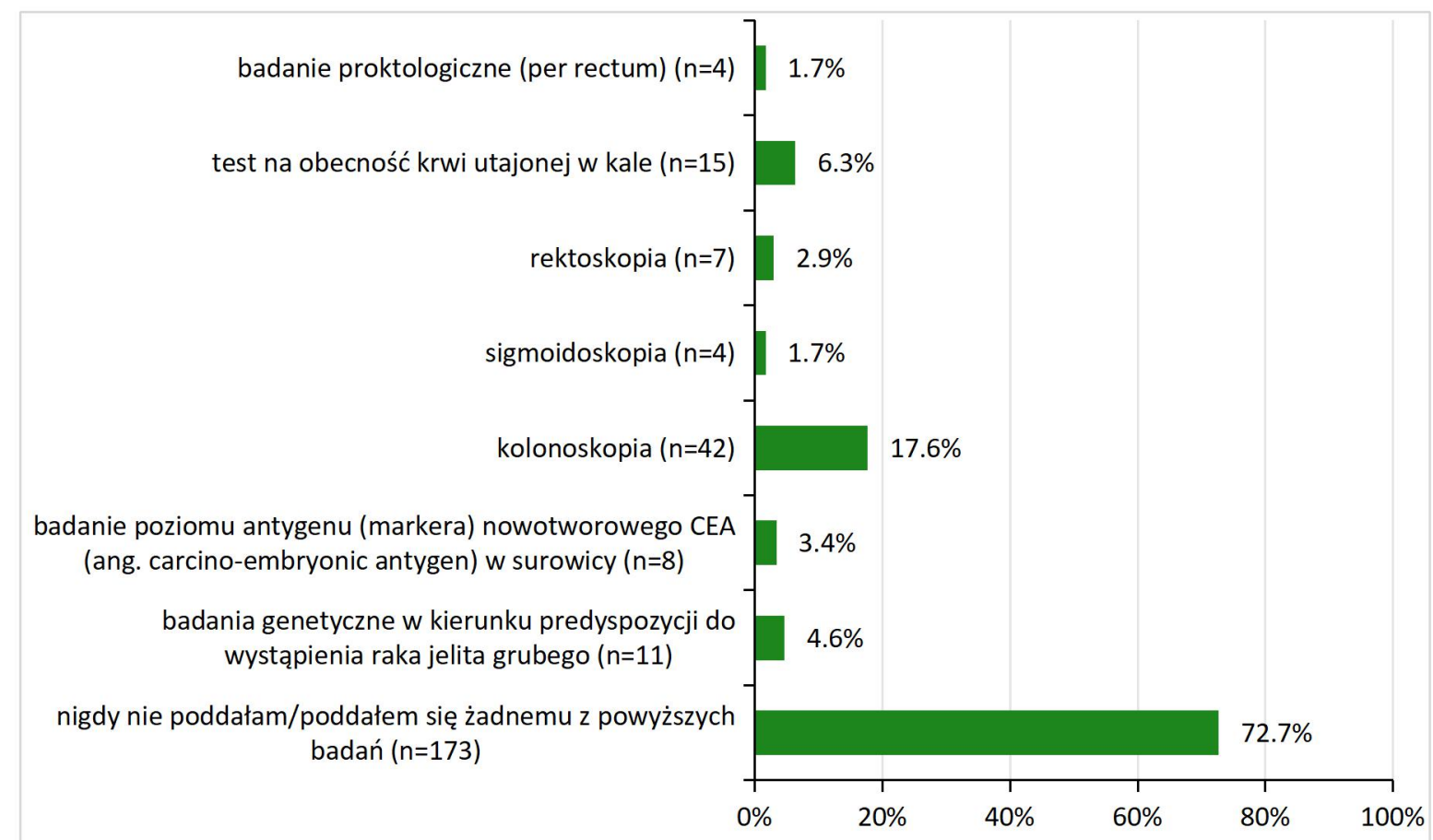

Pytanie wielokrotnego wyboru, wartości nie sumuja się do 100\%

Rycina 6. Badania profilaktyczne wykonywane przez respondentów w przeszłości

$\mathrm{W}$ grupie objętej badaniem, niemal połowa respondentów $(43,7 \%, \mathrm{n}=104)$ uznała poziom własnej wiedzy na temat raka jelita grubego i jego profilaktyki za przeciętny. W opinii nieco ponad jednej trzeciej ankietowanych $(34,5 \%, \mathrm{n}=82)$ poziom własnej wiedzy $\mathrm{w}$ tym zakresie był niski, a co szósta ankietowana osoba $(16,8 \%, n=40)$ uznała go za bardzo niski. Najmniej liczną podgrupę stanowiły osoby, których samoocena wiedzy na temat raka jelita grubego i jego profilaktyki była wysoka $(4,2 \%, n=10)$ i bardzo wysoka $(0,8 \%, n=2)$ (tab. $6)$.

Przeważająca część ankietowanych $(74,8 \%, n=178)$ wiedzę na temat profilaktyki raka jelita grubego czerpała $\mathrm{z}$ Internetu. Kolejnymi, najczęściej wskazywanymi przez respondentów źródłami informacji na ten temat były: telewizja $(28,2 \%, \mathrm{n}=67)$, ulotki informacyjne $(19,7 \%, n=47)$, rodzina $(18,5 \%, n=44)$, a także znajomi $(16 \%, n=38)$. Co dziewiąta ankietowana osoba $(10,9 \%, \mathrm{n}=26)$ wiedzę na temat profilaktyki raka jelita grubego uzyskiwała od lekarza specjalisty w dziedzinie gastroenterologii, chirurgii, onkologii lub radiologii, dla 42 respondentów źródłami informacji były czasopisma $(8,8 \%)$ lub radio $(8,8 \%)$, a wiedzę od lekarza pierwszego kontaktu uzyskało 20 ankietowanych osób $(8,4 \%)$.

Tabela 6. Samoocena wiedzy respondentów na temat raka jelita grubego i jego profilaktyki

\begin{tabular}{|c|c|c|c|}
\hline Zmienne & & Liczba badanych $(n)$ & $\begin{array}{c}\text { Odsetek grupy } \\
\text { badanej (\%) }\end{array}$ \\
\hline \multirow{5}{*}{$\begin{array}{l}\text { Samoocena wiedzy respondentów na temat raka jelita } \\
\text { grubego i jego profilaktyki }\end{array}$} & Bardzo niski & 40 & 16,8 \\
\hline & Niski & 82 & 34,5 \\
\hline & Przeciętny & 104 & 43,7 \\
\hline & Wysoki & 10 & 4,2 \\
\hline & Bardzo wysoki & 2 & 0,8 \\
\hline \multicolumn{2}{|l|}{ Razem } & 238 & 100,0 \\
\hline
\end{tabular}

Chęć poszerzenia własnej wiedzy na temat profilaktyki raka jelita grubego wyraziła zdecydowana większość ankietowanych $(81,1 \%, n=193)$, przy czym 72 respondentów (30,3\% grupy badanej) zdecydowanie chciałoby to zrobić, a 121 ankietowanych $(50,8 \%$ grupy badanej) raczej chciałoby pogłębić własną wiedzę w tym zakresie. Co piąta objęta badaniem 
osoba $(18,9 \%, n=45)$ deklarowała brak potrzeby uzyskania dodatkowych informacji na temat profilaktyki raka jelita grubego (tab. 7).

Tabela 7. Chęć poszerzenia wiedzy w zakresie profilaktyki raka jelita grubego wśród respondentów

\begin{tabular}{|c|c|c|c|}
\hline \multicolumn{2}{|l|}{ Zmienne } & Liczba badanych (n) & $\begin{array}{c}\text { Odsetek grupy } \\
\text { badanej (\%) }\end{array}$ \\
\hline \multirow{4}{*}{$\begin{array}{c}\text { Chęć poszerzenia wiedzy w zakresie profilaktyki raka } \\
\text { jelita grubego wśród respondentów }\end{array}$} & Zdecydowanie tak & 72 & 30,3 \\
\hline & Raczej tak & 121 & 50,8 \\
\hline & Raczej nie & 37 & 15,5 \\
\hline & Zdecydowanie nie & 8 & 3,4 \\
\hline \multicolumn{2}{|l|}{ Razem } & 238 & 100,0 \\
\hline
\end{tabular}

\section{Dyskusja}

Przeprowadzone wśród mieszkańców gminy Czaplinek badanie miało na celu ocenę ich wiedzy na temat raka jelita grubego, a także postaw w zakresie profilaktyki tego nowotworu. W analizowanej grupie, przeważająca część respondentów $(74,8 \%)$ wiedziała, że wczesne rozpoznanie raka jelita grubego znacząco zwiększa szanse na jego wyleczenie. W badaniu Kuprewicz i wsp. [7], którym objęto 248 osób po 20 roku życia, zamieszkujących wiejskie i miejskie tereny województwa warmińsko-mazurskiego, wykazano, że świadomość w tym zakresie posiadało $62,5 \%$ ankietowanych. W badaniu własnym, ze stwierdzeniem, mówiącym o tym, iż ryzyko zachorowania na raka jelita grubego wzrasta wraz z wiekiem, zgodziła się nieco ponad połowa respondentów (57,6\%). Podobnych obserwacji dokonali Kuprewicz i wsp. [7], gdyż wiedzę w tym zakresie posiadało $55,2 \%$ objętych tym badaniem osób. Świadomość tego, że nowotwór złośliwy jelita grubego może rozwijać się bezobjawowo miała połowa grupy objętej analizą własną (50,8\%). Grys i wsp. [26], którzy przeprowadzili badanie wśród 40 mieszkańców województwa świętokrzyskiego w wieku 5080 lat uzyskali porównywalny wynik w tym zakresie - wiedzę na ten temat posiadało 55\% ankietowanych.

$\mathrm{Z}$ badania własnego wynika, iż zaledwie 39,5\% respondentów zgodziło się ze stwierdzeniem, że rak jelita grubego dotyczy częściej mężczyzn niż kobiet. Grys i wsp. [26] oraz Kuprewicz i wsp. [7] uzyskali nieco wyższy, lecz również niezadowalający wynik, gdyż wiedzę w tym zakresie posiadało odpowiednio $45 \%$ i $49,6 \%$ objętych tymi badaniami osób. Z analizy własnej wynika, iż tylko nieco ponad jedna trzecia respondentów $(37,4 \%)$ wiedziała, że rak jelita grubego rozpoznawany jest najczęściej u osób po 50 roku życia, a zaledwie co czwarta ankietowana osoba $(22,3 \%)$ zgodziła się ze stwierdzeniem mówiącym o tym, że większość zgonów z powodu tego nowotworu obserwowana jest wśród osób po 60 roku życia. Niepokojący jest także fakt, iż tylko co piąty respondent (21\%) miał świadomość tego, że rak jelita grubego stanowi drugą najczęstszą przyczynę zgonów $\mathrm{z}$ powodu nowotworów złośliwych $\mathrm{w}$ populacji polskich mężczyzn. Zaskakująco mało ankietowanych - 13\% wiedziało o tym, że ryzyko zgonu z powodu nowotworów złośliwych jelita grubego jest najwyższe u osób, które ukończyły 80 rok życia. $Z$ badania własnego wynika również, że tylko $12,2 \%$ respondentów zgodziło się ze stwierdzeniem dotyczącym tego, iż rak jelita grubego jest drugim co do częstości występowania nowotworem złośliwym, na który zapadają polskie kobiety.

Ze względu na odmienne formułowanie pytań i odpowiedzi dotyczących częstości występowania raka jelita grubego w kwestionariuszach ankiet zastosowanych $\mathrm{w}$ badaniach innych autorów, trudne jest porównanie dokonanych w tej kwestii spostrzeżeń. W badaniu Stefanowicz i wsp. [27], przeprowadzonym wśród 200 losowo wybranych osób po 50 roku życia, wykazano, iż 45,5\% ankietowanych uważało, że rak jelita grubego jest jednym z najczęściej diagnozowanych nowotworów złośliwych w Polsce. Z kolei u Kuprewicz i wsp. [7], o tym, że rak jelita grubego występuje w polskiej populacji często, przekonanych było $48,8 \%$ respondentów. Zadowalający jest fakt, iż niemal wszystkie osoby objęte badaniem 
własnym $(97,1 \%)$ wiedziały, że to starsze osoby chorują na nowotwory złośliwe jelita grubego częściej niż ludzie młodzi.

Do czynników zwiększających prawdopodobieństwo zachorowania na raka jelita grubego respondenci w badaniu własnym zaliczyli głównie: nadwagę lub otyłość $(61,3 \%)$, niską aktywność fizyczną (55,5\%), stany zapalne jelit $(49,6 \%)$, uwarunkowania genetyczne $(49,6 \%)$, stosowanie diety ubogiej w błonnik $(47,1 \%)$, palenie tytoniu $(46,6 \%)$ oraz nadmierne spożywanie alkoholu (45,8\%). W badaniu Gujskiej i wsp. [11], gdzie grupę badaną stanowiło 105 studentów pielęgniarstwa Uniwersytetu Medycznego w Lublinie, najczęściej wskazywanymi czynnikami ryzyka raka jelita grubego były: obecność polipów w jelicie grubym (98\%), obciążenie genetyczne (97\%), a także dieta bogata w czerwone mięso, thuszcze pochodzenia zwierzęcego i węglowodany proste $(95 \%)$. W badaniach innych autorów najbardziej znanym ankietowanym czynnikiem sprzyjającym zachorowaniu na nowotwory złośliwe jelita grubego okazały się być predyspozycje rodzinne i/lub genetyczne [7,26,28]. Niewielu z kolei respondentów objętych badaniem własnym wiedziało, iż do rozwoju raka jelita grubego może przyczynić się również zakażenie HIV (8\%), zakażenie HPV (8\%) oraz posiadanie kilku partnerów seksualnych $(8 \%)$. Są to bowiem czynniki zwiększające prawdopodobieństwo wystąpienia raka odbytu, zaliczanego także do grupy nowotworów złośliwych jelita grubego - C18-C21, a tę właśnie klasyfikację zastosowano w niniejszej pracy. Niski odsetek wskazań tych odpowiedzi wynika najpewniej z tego, iż respondenci, wypełniając kwestionariusz ankiety stworzony na potrzeby badania własnego, nie wiązali nowotworów złośliwych jelita grubego z rakiem odbytu, lub też nieznane im były drogi szerzenia zakażeń HIV i HPV. Najrzadziej z kolei wskazywanymi przez ankietowanych w badaniu własnym czynnikami ryzyka raka jelita grubego były: przebyta cholecystektomia (usunięcie pęcherzyka żółciowego) (5,5\%) oraz niski poziom HDL we krwi (5\%).

Znajomość czynników predysponujących do rozwoju raka jelita grubego stanowi niezbędny element profilaktyki pierwotnej tego nowotworu, dlatego też niezwykle niepokojący jest fakt, iż niemal połowa grupy objętej badaniem własnym (45\%) posiadała niedostateczną wiedzę w tym zakresie. Ocenę dostateczną uzyskało 40,3\% respondentów, dobrą - co dziesiąta ankietowana osoba (10,5\%), natomiast bardzo dobrą znajomością czynników ryzyka raka jelita grubego wykazało się tylko 10 respondentów $(4,2 \%)$. Stefanowicz i wsp. [28] wykazali, że poziom wiedzy ankietowanych na temat czynników ryzyka raka jelita grubego również był niezadowalający - średni odsetek odpowiedzi udzielonych poprawnie w tym badaniu wyniósł 50,3\%. Z kolei z analizy Gujskiej i wsp. [11] wynika, iż niski poziom wiedzy w zakresie czynników zwiększających prawdopodobieństwo wystąpienia raka jelita grubego posiadało $2 \%$ ankietowanych studentów, przeciętny $-30 \%$, natomiast wysoki poziom wiedzy $\mathrm{w}$ tym zakresie zaprezentowało aż $68 \%$ objętych tym badaniem respondentów.

W badaniu własnym, do objawów, mogących świadczyć o rozwoju raka jelita grubego respondenci zaliczyli przede wszystkim: krwawienie podczas wypróżniania $(75,2 \%)$, obecność krwi w/na stolcu (62,2\%), ból brzucha, krocza i/lub odbytu $(49,2 \%)$, spadek masy ciała i/lub ogólne osłabienie organizmu $(47,9 \%)$, a także zaparcia $(39,9 \%)$ i widoczny lub wyczuwalny guz w okolicy odbytu $(34,5 \%)$. Krwawienie podczas wypróżniania było najczęściej wskazywanym przez ankietowanych objawem również w badaniu Grys i wsp. (40\%) [26]. Gujska i wsp. [11] wykazali, iż ankietowani wskazywali najczęściej na: dodatni wynik testu na krew utajoną w kale (95\%), obecność świeżej krwi w stolcu (92\%), a także na zmianę rytmu wypróżnień (87\%). Również w badaniu Kuprewicz i wsp. [7] ankietowani zaznaczali najczęściej obecność krwi w stolcu $(19,9 \%)$ oraz zaparcia na przemian $\mathrm{z}$ biegunkami $(15,6 \%)$, natomiast $\mathrm{w}$ dalszej kolejności pojawiły się: ból w dolnej części brzucha (11\%) oraz uczucie niepełnego wypróżnienia $(10,8 \%)$. Do najrzadziej wskazywanych przez respondentów 
w badaniu własnym objawów raka jelita grubego należały: wąskie „ołówkowate” stolce $(19,3 \%)$, nietrzymanie stolca i/lub gazów $(18,9 \%)$, dyskomfort podczas siedzenia $(17,2 \%)$ oraz świąd okolicy odbytu $(15,1 \%)$. „Ołówkowate stolce” stanowiły jeden z najrzadziej wskazywanych objawów, mogących świadczyć o rozwoju raka jelita grubego również w badaniach Grys i wsp. [26] oraz Kuprewicz i wsp. [7] - odsetek wskazań dla tej odpowiedzi wyniósł odpowiednio 15\% i 7,3\%. Wśród najrzadziej wskazywanych objawów raka jelita grubego w badaniu Grys i wsp. [26] znalazły się również: ból brzucha (15\%), wzdęcia $(12,5 \%)$, wyczuwalny guz $(10 \%)$ oraz gorączka $(10 \%)$ i brak łaknienia $(7,5 \%)$. W analizie przeprowadzonej przez Kuprewicz i wsp. [7] były to również wzdęcia brzucha $(8,3 \%)$ i brak łaknienia $(4,6 \%)$, a także wymioty $(2,1 \%)$.

Ankietowani objęci badaniem własnym posiadali najczęściej dostateczną wiedzę na temat objawów mogących świadczyć o rozwoju raka jelita grubego $(42,9 \%)$, jednak należy zwrócić uwagę na fakt, iż ponad jedna trzecia respondentów $(35,7 \%)$ uzyskała w tym zakresie ocenę niedostateczną. Co ósma ankietowana osoba (12,6\%) wykazała się dobrą znajomością tego zagadnienia, z kolei ocenę bardzo dobrą uzyskało zaledwie 21 respondentów $(8,8 \%)$.

$\mathrm{Z}$ powyższego wynika, iż wiedza badanych na temat objawów raka jelita grubego była nieco lepsza niż w przypadku czynników zwiększających prawdopodobieństwo wystąpienia tego nowotworu, jednak poziom ten jest wciąż zdecydowanie niezadowalający. Z kolei Gujska i wsp. [11] w swoim badaniu wykazali, że niski poziom wiedzy w zakresie objawów, mogących świadczyć o rozwoju raka jelita grubego posiadało $7 \%$ respondentów, przeciętny $25 \%$, natomiast wysoki poziom wiedzy na ten temat zaprezentowało aż $69 \%$ ankietowanych studentów.

Wśród najczęściej identyfikowanych przez respondentów działań, mogących zapobiec zachorowaniu na raka jelita grubego znalazły się: regularna aktywność fizyczna $(68,9 \%)$, stosowanie diety bogatej w błonnik pokarmowy, warzywa, owoce i ryby $(66,4 \%)$, a także utrzymywanie prawidłowej masy ciała $(61,8 \%)$. W badaniu przeprowadzonym przez Kuprewicz i wsp. [7] zaobserwowano, że stosowanie diety, polegającej na ograniczeniu spożywania wysokokalorycznych posiłków, zwiększeniu podaży warzyw, owoców oraz produktów zawierających błonnik pokarmowy, zostało uznane za działanie $\mathrm{z}$ zakresu profilaktyki pierwotnej również przez większość ankietowanych. W badaniu własnym, świadomość na temat korzystnego działania wynikającego $\mathrm{z}$ ograniczenia spożywania alkoholu oraz niepalenia tytoniu posiadała nieco ponad połowa respondentów - odsetek wskazań dla tych odpowiedzi wyniósł odpowiednio: 58,4\% i 52,9\%. Niewiele ankietowanych z kolei wiedziało $(39,1 \%)$, iż do działań zapobiegawczych w kierunku raka jelita grubego można zaliczyć również ograniczenie konsumpcji czerwonego mięsa. Długotrwałe przyjmowanie niesteroidowych leków przeciwzapalnych, w tym kwasu acetylosalicylowego oraz stosowanie hormonalnej terapii zastępczej (HTZ) u kobiet w okresie pomenopauzalnym zostało wskazane przez odpowiednio $15,5 \%$ oraz $10,1 \%$ ankietowanych w badaniu własnym. Należy zwrócić uwagę na fakt, iż działania te co prawda mogą przyczynić się do obniżenia ryzyka rozwoju nowotworów złośliwych jelita grubego, jednak takie postępowanie może wiązać się również z wieloma działaniami niepożądanymi, w związku z czym - zgodnie ze wskazaniami aktualnej wiedzy medycznej - przewlekłe przyjmowanie niesteroidowych leków przeciwzapalnych oraz stosowanie HTZ w ramach profilaktyki raka jelita grubego w populacji ogólnej nie jest obecnie zalecane [8,13,18,20,21,29-32].

Analiza wyników przeprowadzonego badania pozwala twierdzić, iż prezentowany przez respondentów poziom wiedzy dotyczący działań zapobiegających zachorowaniu na raka jelita grubego był zróżnicowany. Co trzecia ankietowana osoba (29,8\%) potrafiła zidentyfikować co najwyżej 2 z 8 wymienionych działań, mogących przyczynić się do obniżenia ryzyka rozwoju raka jelita grubego, uzyskując tym samym niedostateczną ocenę $\mathrm{w}$ tym zakresie. 
Nieco ponad jedna trzecia badanych $(34,5 \%)$ posiadała dostateczną wiedzę na ten temat, $\mathrm{z}$ kolei dobrą $-29 \%$ respondentów. Niestety tylko co piętnasta osoba $(6,7 \%)$ wykazała się bardzo dobrą znajomością tego zagadnienia.

Z przeprowadzonej analizy wynika, iż nie wszyscy respondenci objęci badaniem własnym znali definicję badań skriningowych, gdyż odsetek prawidłowo udzielonych odpowiedzi na to pytanie wyniósł $65,1 \%$.

Zalecanym i stosowanym najczęściej w celu wczesnego wykrycia raka jelita grubego badaniem profilaktycznym jest obecnie kolonoskopia. Wiedziała o tym większość osób objętych badaniem własnym $(63,9 \%)$. Kolejnymi według częstości wskazywania przez respondentów badaniami w tym pytaniu były: test na obecność krwi utajonej w kale $(13 \%)$ oraz badanie kontrastowe jelita grubego (tzw. wlew doodbytniczy) (5\%). W analizie Kuprewicz

i wsp. [7] poprawnej odpowiedzi na to pytanie udzieliło nieco mniej ankietowanych niż w badaniu własnym. Kolonoskopia została uznana za zalecane i najczęściej stosowane badanie przesiewowe $\mathrm{W}$ kierunku raka jelita grubego przez $46,8 \%$ objętych tym badaniem respondentów.

Niepokojącym jest fakt, iż wiek, w jakim należy rozpocząć wykonywanie badań profilaktycznych w kierunku raka jelita grubego (u osób, które nie posiadają objawów ani dodatkowych czynników ryzyka) - 50 rok życia - znany był niespełna jednej trzeciej respondentów objętych badaniem własnym (31,9\%). W analizie Grys i wsp. [26] odnotowano tylko nieco wyższy wskaźnik prawidłowych odpowiedzi na to pytanie. Wiek, w jakim należy rozpocząć wykonywanie badań przesiewowych w kierunku raka jelita grubego właściwie określiło $40 \%$ objętych tym badaniem osób.

Badanie na krew utajoną $\mathrm{w}$ kale jest jedną $\mathrm{z}$ podstawowych metod diagnostycznych, pozwalających na wykrycie nieprawidłowości w obrębie układu pokarmowego. Niewątpliwą zaletą tej metody jest niski koszt oraz jej nieinwazyjność. Test na obecność krwi utajonej w kale może służyć jako badanie skriningowe w kierunku raka jelita grubego, stanowiące szansę na zmniejszenie umieralności z powodu tego nowotworu w skali populacyjnej. Warunkiem jednak skuteczności tego badania jest jego coroczne wykonywanie $[5,13,15,18,20,21,33,34]$. Niestety, niewielu respondentów objętych badaniem własnym $(31,5 \%)$ miało świadomość tego, że badanie na obecność krwi utajonej w kale powinno być wykonywane w odstępach rocznych.

Zadowalającym jest to, że zdecydowana większość respondentów $(79,8 \%)$ w badaniu własnym wiedziała, na czym polega kolonoskopia, wskazując, iż jest to badanie wykonywane po uprzednim przyjęciu środka przeczyszczającego, polegające na wprowadzeniu przez odbyt cienkiego, giętkiego wziernika zakończonego kamerą i ocenie wnętrza całego jelita grubego. Janiak i wsp. [6] przeprowadzili badanie na terenie Trójmiasta wśród 505 osób w wieku 50-65 lat bez objawów alarmowych i innych dolegliwości, mogących wskazywać na konieczność wykonania diagnostycznej kolonoskopii (adresaci Programu Badań Przesiewowych raka jelita grubego). Autorzy tej analizy wykazali, że aż 89\% ankietowanych osób wiedziało, na czym polega badanie kolonoskopowe. Porównanie tych wyników $\mathrm{z}$ wynikami uzyskanymi $\mathrm{w}$ badaniu własnym nie jest jednak możliwe ze względu na odmienne skonstruowanie pytania i kafeterii odpowiedzi dotyczącej tej kwestii. W kwestionariuszu ankiety, którym posłużyły się Janiak i wsp. [6] na pytanie: „Czy wie Pan/Pani, na czym polega badanie kolonoskopowe?” respondenci mieli możliwość udzielenia odpowiedzi „tak” lub „nie”, co oznacza, że zweryfikowano tu jedynie deklarowaną przez ankietowanych znajomość omawianego zagadnienia. W badaniu własnym z kolei sprawdzono faktyczną wiedzę respondentów na ten temat, gdyż dysjunktywna kafeteria odpowiedzi na pytanie: „Na czym według Pana/Pani polega badanie kolonoskopowe?" zawierała opis trzech procedur diagnostycznych oraz odpowiedź „nie wiem”. 
Niezwykle niepokojący jest fakt, że spośród ogółu respondentów objętych badaniem własnym, tylko 31,5\% słyszało o Programie Badań Przesiewowych raka jelita grubego, w ramach którego istnieje możliwość poddania się bezpłatnej kolonoskopii. W analizie Krenzel i wsp. [12], których grupę badaną stanowiło 200 osób po 60 roku życia, zamieszkujących tereny województwa śląskiego, wykazano, że o Programie słyszało 42,5\% respondentów. Kozłowska i Kowalczyk [35] w 2014 roku oceniały wiedzę i postawy wobec Programu Badań Przesiewowych w kierunku wczesnego wykrycia nowotworu jelita grubego wśród 937 pełnoletnich pracowników administracyjno-biurowych zatrudnionych na terenie województwa lubelskiego. W badaniu tym uzyskano również lepszy niż otrzymany w analizie własnej wynik, bowiem o Programie słyszała wówczas niemal połowa respondentów $(45,4 \%)$. Podobnych spostrzeżeń dokonały Janiak i wsp. [6], gdyż znajomość Programu Badań Przesiewowych raka jelita grubego zadeklarowało 49\% objętych tym badaniem osób.

Respondenci, którzy słyszeli o Programie Badań Przesiewowych raka jelita grubego dobrze poradzili sobie ze wskazaniem populacji, do jakiej jest on skierowany. Odpowiedź mówiącą o tym, że do Programu kwalifikują się wszystkie osoby w wieku 50-65 lat bez objawów raka jelita grubego, a także osoby młodsze, obciążone dodatkowym ryzykiem zachorowania na ten nowotwór, zaznaczyło poprawnie 68\% ankietowanych (spośród 75 osób, które zadeklarowały znajomość Programu). Stefanowicz i wsp. [27] również uzyskali dość zadowalający w tej kwestii wynik - populację objętą Programem wskazała poprawnie zdecydowana większość ankietowanych (71,5\%).

Szczególną uwagę należy zwrócić na to, jak bardzo niski był poziom wiedzy ankietowanych na temat tego, jak często można korzystać $z$ bezpłatnych badań kolonoskopowych wykonywanych w ramach Programu w przypadku przeciętnego ryzyka zachorowania na raka jelita grubego. Odstęp dziesięcioletni w odpowiedzi na to pytanie poprawnie wskazało tylko 18,7\% respondentów, którzy słyszeli o Programie. Kozłowska i Kowalczyk [35] dokonały podobnych spostrzeżeń w tym zakresie. W powyższej analizie, świadomość tego, że bezpłatnej kolonoskopii w ramach Programu mogą poddać się osoby spełniające kryterium wieku i dodatkowo, które w okresie ostatnich 10 lat nie wykonywały tego badania, miało zaledwie 25,9\% respondentów deklarujących znajomość szczegółów Programu Badań Przesiewowych raka jelita grubego.

$\mathrm{Z}$ analizowanego materiału badawczego wynika, iż respondenci posiadali najczęściej dostateczny poziom wiedzy na temat raka jelita grubego i jego profilaktyki - ocenę taką uzyskało 62,5\% ankietowanych. Dobrą ogólną znajomość tych zagadnień prezentował co szósty respondent $(16 \%)$, natomiast bardzo dobrą wiedzą wykazało się tylko 8 respondentów $(3,4 \%)$. Co piąta ankietowana osoba $(18,1 \%)$ na podstawie odpowiedzi udzielonych $\mathrm{w}$ pytaniach weryfikujących wiedzę na temat raka jelita grubego i jego profilaktyki uzyskała ocenę niedostateczną. Grys i wsp. [26] ocenili ogólny poziom wiedzy respondentów na temat raka jelita grubego jako średni, gdyż średnia wszystkich prawidłowo udzielonych odpowiedzi w tym badaniu wyniosła $61 \%$. W analizie Kuprewicz i wsp. [7] wykazano, że ponad połowa ankietowanych $(58,9 \%)$ posiadała niski poziom wiedzy na temat raka jelita grubego i jego profilaktyki. Średnią znajomość omawianego tematu prezentowało 38,7\% respondentów, natomiast wysokim poziomem wiedzy wykazało się zaledwie $2,4 \%$ objętych tym badaniem osób. Markowska i wsp. [36] przeprowadziły badanie wśród 215 wybranych losowo pełnoletnich pacjentów podstawowej opieki zdrowotnej w województwie zachodniopomorskim. Na podstawie analizy danych zebranych w tym badaniu stwierdzono, iż poziom wiedzy ankietowanych na temat raka jelita grubego był niewystarczający. W analizie własnej nie wykazano istotnych statystycznie zależności między ogólnym poziomem wiedzy na temat raka jelita grubego i jego profilaktyki a płcią respondentów. Takich spostrzeżeń dokonała również Markowska i wsp. [36]. Z kolei w badaniu Kuprewicz i wsp. [7] wykazano, że kobiety posiadały znamiennie wyższy ogólny poziom wiedzy w tym zakresie 
niż mężczyźni. Suma uzyskanych punktów w pytaniach weryfikujących wiedzę na temat raka jelita grubego i jego profilaktyki nie różniła się istotnie statystycznie w zależności od wieku ankietowanych objętych badaniem własnym. Markowska i wsp. [36] uzyskały porównywalny wynik w tej kwestii, natomiast w publikacji Kuprewicz i wsp. [7] nie zamieszczono analizy dotyczącej ogólnej wiedzy ankietowanych w omawianym zakresie według wieku. W badaniu własnym nie wykazano także znamiennego związku między poziomem wiedzy na temat raka jelita grubego i jego profilaktyki a miejscem zamieszkania respondentów. Z kolei u Kuprewicz i wsp. [7] odnotowano istotne statystycznie różnice w tej kwestii. Wykazano, że osoby zamieszkujące miasto posiadały znamiennie wyższy ogólny poziom wiedzy w omawianym zakresie niż mieszkańcy wsi. $Z$ analizy przeprowadzonej przez Markowską i wsp. [36] wynika, że mieszkańcy wsi wskazali najmniej prawidłowych odpowiedzi oraz udzielili najwięcej odpowiedzi błędnych. W badaniu tym wykazano, że ogólny poziom wiedzy na temat raka jelita grubego i jego profilaktyki zaprezentowany przez osoby zamieszkujące miasta do 100 tys. mieszkańców był istotnie statystycznie wyższy od tego, który posiadały osoby zamieszkujące tereny wiejskie. Podobnych spostrzeżeń dokonali również Grys i wsp. [26], bowiem średnia wszystkich poprawnie wskazanych odpowiedzi w tym badaniu dla mieszkańców miast wyniosła $66 \%$, natomiast dla osób zamieszkujących tereny wiejskie $48 \%$. Ponadto wykazano, iż różnica $w$ tej kwestii zauważalna była $w$ każdym $\mathrm{z} 13$ zamkniętych pytań dotyczących zagadnień związanych $\mathrm{z}$ rakiem jelita grubego, zawartych w autorskim kwestionariuszu ankiety zastosowanym $\mathrm{w}$ tym badaniu. W powyższej publikacji nie zawarto jednak wyników analizy statystycznej, a wspomniane wnioski zostały sformułowane $\mathrm{W}$ oparciu o analizę porównawczą wartości procentowych dla danych pochodzących $\mathrm{z}$ tego badania. Suma uzyskanych punktów przez respondentów w badaniu własnym różniła się istotnie statystycznie w zależności od ich wykształcenia. Najwyższa ogólna znajomość omawianych zagadnień charakteryzowała osoby $z$ wyższym wykształceniem, co zbieżne jest z wynikami uzyskanymi przez Markowską i wsp. [36]. W badaniu własnym stwierdzono, że ankietowani $\mathrm{z}$ wykształceniem wyższym wykazali się znamiennie większą ogólną znajomością zagadnień związanych z rakiem jelita grubego i jego profilaktyką niż respondenci z wykształceniem zasadniczym zawodowym. Jest to tożsame ze spostrzeżeniami Markowskiej i wsp. [36], przy czym w badaniu tym dodatkowo wykazano także istotne różnice $\mathrm{w}$ ogólnym poziomie wiedzy między osobami $\mathrm{z}$ wykształceniem wyższym a respondentami $\mathrm{z}$ wykształceniem podstawowym. Analiza wyników badania własnego wskazała również na istotne statystycznie zależności między poziomem wiedzy na temat raka jelita grubego i jego profilaktyki a występowaniem nowotworów jelita grubego wśród krewnych respondentów. Najwyższą ogólną znajomością tego zagadnienia wykazali się ankietowani potwierdzający rodzinne obciążenie tymi nowotworami. Obserwacje te są równoważne $\mathrm{z}$ dokonanymi przez Markowską i wsp. [36]. Analiza wyników badania własnego pozwala stwierdzić, że ogólny poziom wiedzy zaprezentowany przez osoby potwierdzające wywiad rodzinny obciążony występowaniem nowotworów jelita grubego różnił się znamiennie od wiedzy zaprezentowanej przez ankietowanych, którzy nie wiedzieli, czy wśród ich krewnych występowały przypadki zachorowania na te nowotwory. Wskazuje to, iż styczność z problematyką raka jelita grubego poprzez doświadczenia bliskich korzystnie wpływa na wiedzę oraz świadomość zdrowotną w tym zakresie. Brak rozeznania, tym samym najprawdopodobniej zainteresowania kwestią rodzinnej przeszłości chorobowej związanej z nowotworami jelita grubego pokrywa się z kolei z niską znajomością zagadnień dotyczących raka jelita grubego i jego profilaktyki.

Program Badań Przesiewowych raka jelita grubego realizowany jest w Polsce od 2000 roku, jednak poziom zgłaszalności na badania kolonoskopowe wykonywane w jego ramach jest wciąż zatrważająco niski $[5,6,13,23,25]$. Niepokojących obserwacji w tej kwestii dokonano również w badaniu własnym. Spośród 54 ankietowanych po 50 roku życia, tylko 5 
(9,3\%) zadeklarowało, że w przeszłości skorzystało z bezpłatnego badania kolonoskopowego w ramach Programu Badań Przesiewowych raka jelita grubego. Podobnych spostrzeżeń dokonały Janiak i wsp. [6], gdyż w badaniu tym zaledwie co dziesiąta ankietowana osoba w wieku 50-65 lat (9\%) potwierdziła udział w Programie w przeszłości. U Kozłowskiej i Kowalczyk [35] badaniom przesiewowym w kierunku wczesnego wykrycia raka jelita grubego poddało się z kolei kiedykolwiek 17,5\% ankietowanych po 50 roku życia. Lepszy wynik w tym zakresie uzyskali Krenzel i wsp. [12], gdzie niemal jedna trzecia badanej populacji seniorów (osób po 60 roku życia) (28\%) korzystała w przeszłości z badań realizowanych $w$ ramach programów profilaktyki raka jelita grubego, gdyż otrzymała na nie zaproszenie.

W cytowanej analizie wykazano też, że tyle samo ankietowanych $(27 \%)$ zadeklarowało, iż z uwagi na troskę o własne zdrowie badania te wykonuje regularnie. Nadal jednak nie są to zadowalające dane, a obecna sytuacja wymaga pilnej poprawy.

Respondenci po 50 roku życia, którzy nigdy nie poddali się bezpłatnej kolonoskopii w ramach Programu Badań Przesiewowych raka jelita grubego, jako najczęstszą tego przyczynę podawali brak wiedzy o takiej możliwości (57,1\%). Kolejnymi według częstości wskazywania przez ankietowanych przyczynami tego były: ograniczony dostęp do badań diagnostycznych na zamieszkiwanym obszarze $(38,8 \%)$, krępująca forma badania $(24,5 \%)$, lęk przed bólem podczas badania $(24,5 \%)$, a następnie - lęk przed zdiagnozowaniem choroby $(12,2 \%)$ oraz brak zaufania do specjalistów $(12,2 \%)$. W badaniach innych autorów pytania dotyczące przyczyn niezgłaszania się na badania skriningowe w kierunku raka jelita grubego skierowane zostały do wszystkich ankietowanych, a zastosowana kafeteria odpowiedzi w tych pytaniach, w przeciwieństwie do badania własnego, była dysjunktywna. U Janiak i wsp. [6] za czynniki zniechęcające do poddania się kolonoskopii respondenci uznali przede wszystkim: krępującą formę badania (21\%), strach przed bólem (17\%), brak konieczności wykonania badania ze względu na nieobecność objawów (16\%), a także brak możliwości skorzystania ze znieczulenia (15\%). W analizie Stefanowicz i wsp. [27] z kolei główną przyczyną biernej postawy wobec badań przesiewowych w kierunku raka jelita grubego był strach przed ciężką, nieuleczalną chorobą (42\%). Przekonanie o byciu zdrowym zostało uznane w tym badaniu za czynnik powodujący niezgłaszanie się na badania kolonoskopowe przez $38 \%$ ankietowanych, z kolei brak wiedzy o możliwości poddania się takim badaniom wskazał co piąty respondent (20\%). Kuprewicz i wsp. [7] wykazali natomiast, że do głównych przyczyn rezygnacji z kolonoskopii ankietowani zaliczyli: długi czas trwania badania, lęk przed badaniem oraz bólem podczas jego wykonywania, a także utrudniony dostęp do badań przesiewowych w kierunku raka jelita grubego.

Ankietowanych po 50 roku życia, którzy nigdy nie brali udziału w Programie Badań Przesiewowych raka jelita grubego zapytano również o zamiar zgłoszenia się na bezpłatne przesiewowe badanie kolonoskopowe. Niepokojącym jest fakt, iż tylko co czwarty odpowiadający na to pytanie respondent $(26,5 \%)$ wyraził wolę poddania się temu badaniu.

U Kozłowskiej i Kowalczyk [35] chęć uczestnictwa w Programie po otrzymaniu imiennego zaproszenia wyraziła nieco ponad jedna trzecia ankietowanych, którzy wcześniej nie poddali się przesiewowej kolonoskopii (38,3\%). Autorzy pozostałych badań o zamiar i chęć wykonania badania kolonoskopowego zapytali wszystkich respondentów. Janiak i wsp. [6] wykazały, że zamiar zgłoszenia się na bezpłatną kolonoskopię w ramach Programu jednoznacznie zadeklarowała połowa grupy badanej (51\%), którą stanowiły osoby w wieku 50-65 lat. W analizie Kuprewicz i wsp. [7] z kolei wykazano, że kolonoskopii poddałoby się $53,6 \%$ objętych tym badaniem osób po ukończeniu 20 roku życia.

Niepokojącym jest fakt, iż spośród ogółu ankietowanych $\mathrm{w}$ badaniu własnym, niemal trzy czwarte $(72,7 \%)$ zadeklarowało, że nigdy nie poddało się żadnemu z badań w kierunku raka jelita grubego. Badanie kolonoskopowe zrealizowało w przeszłości zaledwie 17,6\% 
respondentów, test na obecność krwi utajonej w kale $-6,3 \%$, z kolei badania genetyczne $\mathrm{w}$ kierunku predyspozycji do wystąpienia raka jelita grubego zostały wykonane u 4,6\% ankietowanych. Stefanowicz i wsp. [27,28] uzyskali nieco gorszy niż w badaniu własnym wynik, bowiem badaniu kolonoskopowemu poddało się $\mathrm{w}$ przeszłości tylko 14,5\% wszystkich ankietowanych (osoby w wieku 50-65 lat). Analiza materiału badawczego zebranego przez Markowską i wsp. [36] wykazała, że kolonoskopię zrealizowała w przeszłości jedna czwarta populacji badanej (24,2\%), którą stanowili losowo wybrani pełnoletni pacjenci podstawowej opieki zdrowotnej. Z kolei u Krenzel i wsp. [12], których grupę badaną stanowiły osoby w wieku powyżej 60 lat, tylko co czwarty respondent $(23 \%)$ zadeklarował, że w przeszłości nie wykonywał żadnych badań w kierunku raka jelita grubego.

Ankietowani różnie oceniali własną znajomość zagadnień związanych z rakiem jelita grubego i jego profilaktyką. W opinii niemal połowy respondentów $(43,7 \%)$ poziom ich wiedzy w tym zakresie był przeciętny. Co trzecia ankietowana osoba $(34,5 \%)$ uważała, że poziom jej wiedzy był niski, a co szósty respondent (16,8\%) uznał go za bardzo niski. Należy zwrócić również uwagę na to, jak niewielu respondentów oceniło poziom własnej wiedzy jako wysoki $(4,2 \%)$ i bardzo wysoki $(0,8 \%)$. Uzyskane wyniki świadczą o tym, iż ankietowani mieli świadomość istnienia obszarów wymagających uzupełnienia $\mathrm{w}$ omawianym w niniejszej pracy zakresie.

Zdecydowana większość respondentów $(74,8 \%)$ informacje na temat profilaktyki raka jelita grubego czerpała z Internetu. W następnej kolejności ankietowani natomiast wskazywali: telewizję $(28,2 \%)$, ulotki informacyjne $(19,7 \%)$, rodzinę $(18,5 \%)$ oraz znajomych $(16 \%)$. Lekarz specjalista w dziedzinie gastroenterologii, chirurgii, onkologii lub radiologii stanowił źródło wiedzy dla co dziewiątej ankietowanej osoby (10,9\%), z kolei od lekarza pierwszego kontaktu informacje czerpało tylko $8,4 \%$ respondentów. Zbliżonych spostrzeżeń dokonali Kuprewicz i wsp. [7], bowiem najczęściej wskazywanymi w tym badaniu źródłami wiedzy na temat raka jelita grubego były również: telewizja (20,9\%), Internet $(19,6 \%)$ oraz znajomi $(18,3 \%)$, zaś od lekarza informacje uzyskiwało - podobnie jak w badaniu własnym $(8,4 \%)-$ tylko $8,2 \%$ ankietowanych. Przedstawione powyżej wyniki, wskazujące na to, jak niewiele osób rozmawia ze specjalistami o profilaktyce raka jelita grubego, potwierdzają, iż zagadnienia związane ze schorzeniami jelita grubego pozostają wciąż krępującym dla społeczeństwa tematem. Problem ten bezpośrednio uwidocznili Kuprewicz i wsp. [7], gdyż $80,6 \%$ ankietowanych w tym badaniu osób przyznało, że wstydzi się mówić o jakichkolwiek dolegliwościach związanych z jelitem grubym. Należy zatem dążyć do poprawy relacji lekarz-pacjent, gdyż to właśnie profesjonaliści medyczni, będący najbardziej rzetelnym źródłem wiedzy, powinni pełnić jedną z najważniejszych ról w szeroko rozumianym procesie profilaktyczno-diagnostycznym nowotworów złośliwych, w tym również raka jelita grubego. Należy także zwrócić szczególną uwagę na weryfikację wiarygodności informacji na temat profilaktyki raka jelita przekazywanych w mediach. Ma to ogromne znaczenie w kontekście skutecznej edukacji społeczeństwa $\mathrm{w}$ omawianym zakresie, ponieważ to właśnie środki masowego przekazu - jak wykazano w badaniu własnym oraz porównywanej w tym obszarze publikacji [7] - stanowiły dla ankietowanych główne źródło informacji

na temat profilaktyki raka jelita grubego.

Zadowalający jest fakt, iż zdecydowana większość respondentów objętych badaniem własnym $(81,1 \%)$ wyraziła chęć poszerzenia własnej wiedzy w zakresie profilaktyki raka jelita grubego. Podobnych obserwacji dokonali Kuprewicz i wsp. [7], gdzie wolę pogłębienia wiedzy na temat raka jelita grubego zadeklarowała również przeważająca część ankietowanych. W cytowanej publikacji nie zamieszczono jednak wartości procentowych dotyczących udzielonych $\mathrm{w}$ tym pytaniu odpowiedzi, dlatego też niemożliwe jest szczegółowe porównanie wyników tego badania $\mathrm{w}$ omawianej kwestii $\mathrm{z}$ wynikami uzyskanymi w analizie własnej. 
Analiza wyników przeprowadzonego badania potwierdziła, jak istotnym problemem jest niski poziom wiedzy społeczeństwa w zakresie raka jelita grubego i jego profilaktyki. Istnieje pilna konieczność prowadzenia zintensyfikowanych działań edukacyjnych na szeroką skalę, w szczególności w obszarze czynników ryzyka i objawów raka jelita grubego, oraz - co najistotniejsze - metod służących zapobieganiu i wczesnemu wykryciu choroby. Należy dążyć do rozpowszechnienia badań przesiewowych w kierunku raka jelita grubego oraz do zwiększenia roli profesjonalistów w profilaktyce tego nowotworu, w tym także specjalistów zdrowia publicznego. Tylko wiarygodne informacje bowiem stanowią gwarancję poprawy świadomości zdrowotnej społeczeństwa oraz wykształcenia prawidłowych postaw wobec profilaktyki onkologicznej, co z kolei jest warunkiem niezbędnym do osiągnięcia poprawy sytuacji epidemiologicznej raka jelita grubego w Polsce.

\section{Wnioski}

1. Znajomość czynników ryzyka oraz objawów raka jelita grubego w grupie badanej była niska.

2. Poziom wiedzy ankietowanych na temat działań zapobiegających zachorowaniu na raka jelita grubego był niezadowalający.

3. Stwierdzono istotne statystycznie zależności między ogólnym poziomem wiedzy na temat raka jelita grubego $\mathrm{i}$ jego profilaktyki a wykształceniem ankietowanych oraz występowaniem nowotworów jelita grubego wśród ich krewnych.

4. Tylko co jedenasty badany po 50 roku życia skorzystał kiedykolwiek z bezpłatnego badania kolonoskopowego w ramach Programu Badań Przesiewowych raka jelita grubego. Głównymi przyczynami niezgłaszania się na te badania były: brak wiedzy o możliwości skorzystania $\mathrm{z}$ badania, ograniczony dostęp do badań diagnostycznych na zamieszkiwanym obszarze, krępująca forma badania oraz lęk przed bólem, mogącym wystąpić podczas jego wykonywania.

5. Zdecydowana większość objętych badaniem respondentów wyraziła chęć poszerzenia własnej wiedzy w zakresie profilaktyki raka jelita grubego.

6. Zdecydowanie niezadowalający poziom wiedzy oraz postaw w zakresie raka jelita grubego i jego profilaktyki wśród mieszkańców gminy Czaplinek wskazuje na pilną potrzebę podjęcia działań, zmierzających do poprawy świadomości społecznej w tym zakresie, skupiających się głównie na promowaniu regularnych badań profilaktycznych.

\section{Piśmiennictwo}

1. Didkowska J, Wojciechowska U, Czaderny K, Olasek P, Ciuba A. Nowotwory złośliwe w Polsce w 2017 roku. Warszawa: Centrum Onkologii - Instytut im. Marii SkłodowskiejCurie; 2019.

2. Wojciechowska U, Didkowska J, Michałek I, Olasek P, Ciuba A. Nowotwory złośliwe w Polsce w 2018 roku. Warszawa: Narodowy Instytut Onkologii im. Marii SkłodowskiejCurie - Państwowy Instytut Badawczy; 2020.

3. Wojciechowska U, Didkowska J. Zachorowania i zgony na nowotwory złośliwe w Polsce. Krajowy Rejestr Nowotworów, Narodowy Instytut Onkologii im. Marii Skłodowskiej-Curie - Państwowy Instytut Badawczy. http://onkologia.org.pl/raporty/ (dostęp: 2021.02.03).

4. Wojciechowska U, Didkowska J. Zachorowania i zgony na nowotwory złośliwe w Polsce. Krajowy Rejestr Nowotworów, Narodowy Instytut Onkologii im. Marii Skłodowskiej-Curie - Państwowy Instytut Badawczy.

http://onkologia.org.p1/nowotwory-zlosliwe-jelita-grubego-c18-21/ (dostęp: 2021.02.03).

5. Wyrwicz L, Gryglewicz J, Chrostowski S, Domańska-Sadynica M, Ambroziewicz B. Sytuacja pacjenta $z$ nowotworem jelita grubego w Polsce. Propozycje zmian. Warszawa: Fundacja Polska Koalicja Pacjentów Onkologicznych, Fundacja Wygrajmy Zdrowie; 2017. 
6. Janiak M, Głowacka P, Kopeć A, Staśkiewicz A. Czynniki determinujące zgłaszalność na badania kolonoskopowe w Programie Badań Przesiewowych raka jelita grubego w Polsce. Gastroenterol Klin. 2016;8(4):142-151.

7. Kuprewicz A, Krajewska-Kułak E, Trochimowicz L. Wiedza na temat raka jelita grubego i preferowane zachowania zdrowotne mieszkańców miasta i wsi. Pielęg Chir Angiol. 2016;2:74-83.

8. Zyśk R, Wysocki P, Wyrwicz L. Rak jelita grubego - społeczne znaczenie zmian w zakresie epidemiologii i możliwości leczenia w Polsce. Onkol Prakt Klin. 2014;10(4):212-223. 9. Deptała A. Epidemiologia, wskaźniki przeżycia, środowiskowe uwarunkowania rozwoju raka jelita grubego. W: Deptała A, Wojtukiewicz MZ, (red.). Rak jelita grubego. Poznań: Termedia Wydawnictwa Medyczne;2018:13-17.

10. Chrobak-Bień JZ, Gawor A, Gąsiorowska A. Wiedza chorych na temat czynników ryzyka i profilaktyki raka jelita grubego. Piel Zdr Publ. 2016;6(3):187-195.

11. Gujska D, Gutek A, Gajewska N, Gawron Ż, Rząca M, Szadowska-Szlachetka Z. Zachowania zdrowotne studentów pielęgniarstwa $\mathrm{w}$ zakresie profilaktyki chorób nowotworowych. J Educ Health Sport. 2016;6(6):107-120.

12. Krenzel I, Bilewicz-Wyrozumska T, Rogozińska E, Słoma M, Bilewicz-Stebel M, Malczyk W, Ślepecki D, Szwajnoch M, Niciak D. Ocena wiedzy na temat wybranych programów profilaktycznych raka jelita grubego w populacji osób starszych. W: Turowski K. (red.). Zdrowie publiczne standardem dobrostanu. Lublin: Wydawnictwo Naukowe NeuroCentrum;2018:187-201.

13. Reguła J, Chaber-Ciopińska A. Profilaktyka pierwotna i wtórna raka jelita grubego.

W: Andrzej D, Wojtukiewicz MZ. (red.). Rak jelita grubego. Poznań: Termedia Wydawnictwa Medyczne;2018:55-65.

14. Kałędkiewicz E, Doboszyńska A. Dietoprofilaktyka raka jelita grubego. Onkol Prak Klin. 2012;8(5):171-177.

15. Binefa G, Rodríguez-Moranta F, Teule A, Medina-Hayas M. Colorectal cancer: from prevention to personalized medicine. World J Gastroenterol. 2014;20(22):6786-6808.

16. Powalski G, Rydzewska G. Objawy podmiotowe, przedmiotowe oraz standardy rozpoznania raka jelita grubego. W: Deptała A, Wojtukiewicz MZ. (red.). Rak jelita grubego. Poznań: Termedia Wydawnictwa Medyczne;2018:67-78.

17. Ahmed S, Johnson K, Ahmed O, Iqbal N. Advances in the management of colorectal cancer: from biology to treatment. Int J Colorectal Dis. 2014;29(9):1031-1042.

18. Siepsiak M, Połom A, Adrych K. Profilaktyka raka jelita grubego. Farm Współ. 2015;8:

$1-5$.

19. Musińska M, Minkiewicz M, Wasielica-Berger J, Kidrycki K, Kurek K. Badania przesiewowe w profilaktyce raka jelita grubego. Med Rodz. 2018;21(3):232-244.

20. Potemski P, Polkowski W, Bujko K, Didkowska J, Guzel Z, Herman R, Łacko A, Olszewski W, Pałucki J, Reguła J. Nowotwory układu pokarmowego. W: Potemski P, Polkowski W. (red.). Zalecenia postępowania diagnostyczno-terapeutycznego W nowotworach złośliwych

- 2013 r. Gdańsk: Via Medica;2013:103-211.

21. Wojciechowska U, Didkowska J. Zachorowania i zgony na nowotwory złośliwe w Polsce. Krajowy Rejestr Nowotworów, Narodowy Instytut Onkologii im. Marii Skłodowskiej-Curie

- Państwowy Instytut Badawczy. http://onkologia.org.pl/nowotwory-jelita-grubego/ (dostęp: 2021.02.19).

22. US Preventive Services Task Force, Bibbins-Domingo K, Grossman DC, Curry SJ, Davidson KW, Epling JW Jr, García FAR, Gillman MW, Harper DM, Kemper AR, Krist AH, Kurth AE, Landefeld CS, Mangione CM, Owens DK, Phillips WR, Phipps MG, Pignone MP, 
Siu AL. Screening for Colorectal Cancer: US Preventive Services Task Force Recommendation Statement. JAMA. 2016;315(23):2564-2575.

23. Narodowy Instytut Onkologii im. Marii Skłodowskiej-Curie - Państwowy Instytut Badawczy. Program Badań Przesiewowych raka jelita grubego (PBP) - o programie. http://pbp.org.pl/program/ (dostęp: 2021.03.10).

24. Program wieloletni pn. Narodowa Strategia Onkologiczna na lata 2020-2030. Załącznik nr 1 do uchwały nr 10 Rady Ministrów z dnia 4 lutego 2020 r. w sprawie przyjęcia programu wieloletniego pn. Narodowa Strategia Onkologiczna na lata 2020-2030 (M.P. 2020 poz. 189). http://isap.sejm.gov.pl/isap.nsf/DocDetails.xsp?id=WMP20200000189 (dostęp: 2021.03.10).

25. Narodowy Instytut Onkologii im. Marii Skłodowskiej-Curie - Państwowy Instytut Badawczy. Program Badań Przesiewowych raka jelita grubego (PBP) - statystyki. http://pbp.org.pl/program/statystyki/ (dostęp: 2021.03.11).

26. Grys AA, Czarnecka J, Sienkiewicz Z, Krupienicz A. Wiedza mieszkańców województwa świętokrzyskiego na temat raka jelita grubego. Piel Pol. 2013;1(47):23-27.

27. Stefanowicz A, Kulik TB, Skórzyńska H, Środa M. Wiedza o programie profilaktyki raka jelita grubego wśród osób w wieku 50-65 lat. Geriatria. 2017;11:259-264.

28. Stefanowicz A, Kulik TB, Środa M, Skórzyńska H, Pacian A. Ocena wiedzy i świadomości osób po 50. roku życia w zakresie czynników ryzyka raka jelita grubego. Fam Med Prim Care Rev. 2015;17(3):210-214.

29. Kmieć N, Wełnicka-Jaśkiewicz M, Jassem J. Niesteroidowe leki przeciwzapalne w profilaktyce i leczeniu nowotworów jelita grubego. Nowotwory J Oncol. 2014;64(2):175-179.

30. Algra AM, Rothwell PM. Effects of regular aspirin on long-term cancer incidence and metastasis: a systematic comparison of evidence from observational studies versus randomised trials. Lancet Oncol. 2012;13(5):518-527.

31. Tárraga López PJ, Albero JS, Rodríguez-Montes JA. Primary and secondary prevention of colorectal cancer. Clin Med Insights Gastroenterol. 2014;7:33-46.

32. Rothwell PM, Price JF, Fowkes FG, Zanchetti A, Roncaglioni MC, Tognoni G, Lee R, Belch JF, Wilson M, Mehta Z, Meade TW. Short-term effects of daily aspirin on cancer incidence, mortality, and non-vascular death: analysis of the time course of risks and benefits in 51 randomised controlled trials. Lancet. 2012;379(9826):1602-1612.

33. Billiau A, Bouche G, Jezdic S, Labianca R, Glimelius B, Van Cutsem E, Arnold D, Kornek G, Ugarte A, Szymanik M. Rak jelita grubego: poradnik dla pacjentów - informacje oparte na wytycznych ESMO (ang. European Society for Medical Oncology - Europejskie Towarzystwo Onkologii Klinicznej) dotyczących praktyki klinicznej - wer. 2016.1. The Anticancer Fund; 2016.

34. Kościelniak-Merak B, Radosavljević B, Zając A, Tomasik PJ. Faecal Occult Blood Point-of-Care Tests. J Gastrointest Canc. 2018;49:402-405.

35. Kozłowska E, Kowalczyk A. Wiedza i postawy pracowników biurowych wobec Programu Badań Przesiewowych w kierunku wczesnego wykrycia nowotworu jelita grubego. J Educ Health Sport. 2015;5(9):443-456.

36. Markowska A, Górka J, Grochans E, Szkup M. Ocena wiedzy wybranych grup społecznych na temat profilaktyki raka jelita grubego. Med Og Nauk Zdr. 2016;22(4):303-306. 


\section{ZAŁĄCZNIK - AUTORSKI KWESTIONARIUSZ ANKIETY}

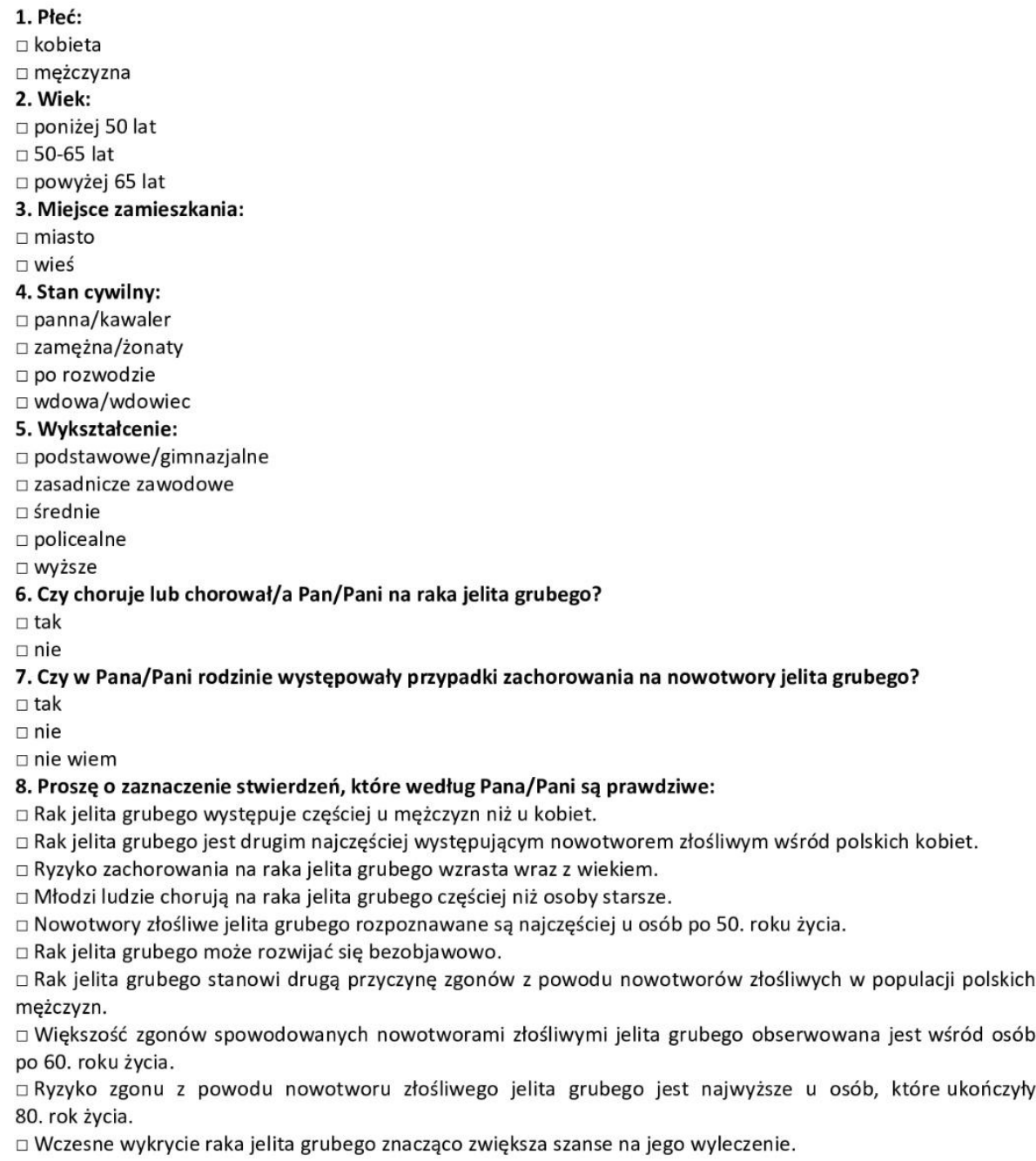

$\square$ Większość zgonów spowodowanych nowotworami złośliwymi jelita grubego obserwowana jest wśród osób po 60 . roku życia.

$\square$ Ryzyko zgonu z powodu nowotworu złośliwego jelita grubego jest najwyższe u osób, które ukończyły 80. rok życia.

$\square$ Wczesne wykrycie raka jelita grubego znacząco zwiększa szanse na jego wyleczenie. 
9. Które z czynników według Pana/Pani zwiększają ryzyko zachorowania na raka jelita grubego? (można zaznaczyć więcej niż jedną odpowiedź)

$\square$ wiek powyżej 50. roku życia

$\square$ nadwaga lub otyłość

$\square$ niska aktywność fizyczna

$\square$ palenie tytoniu

$\square$ nadmierne spożywanie alkoholı

$\square$ dieta uboga w błonnik

$\square$ wysoka zawartość tłuszczów nasyconych i/lub czerwonego mięsa w diecie

$\square$ niedobór wapnia

$\square$ posiadanie kilku partnerów seksualnych

$\square$ odbywanie biernych stosunków analnych

$\square$ zakażenie wirusem HPV (ang. human papilloma virus - wirus brodawczaka ludzkiego)

$\square$ zakażenie wirusem HIV (ang. human immunodeficiency virus - ludzki wirus niedoboru odporności)

$\square$ niski poziom HDL (ang. high density lipoprotein - lipoproteina wysokiej gęstości) we krwi

$\square$ cukrzyca

$\square$ nadciśnienie tętnicze

$\square$ zachorowanie na raka jelita grubego w przeszłości

$\square$ współwystępowanie lub przebyte inne nowotwory

$\square$ wywiad rodzinny obciążony występowaniem raka jelita grubego i/lub innego nowotworu

$\square$ obecność polipów gruczolakowych w jelicie grubym

$\square$ stany zapalne jelit (wrzodziejące zapalenie jelita grubego i/lub choroba Leśniowskiego-Crohna)

$\square$ przebyta radioterapia miednicy małej (obszaru jamy brzusznej)

$\square$ przebyta cholecystektomia (usunięcie pęcherzyka żółciowego)

$\checkmark$ uwarunkowania genetyczne (m. in. rodzinna polipowatość gruczolakowata (FAP - ang. familial adenomatous polyposis) i/lub zespół Lyncha)

10. Jakie objawy według Pana/Pani mogą świadczyć o raku jelita grubego?

(można zaznaczyć więcej niż jedną odpowiedź)

$\square$ krwawienie podczas wypróżniania

$\square$ zmiana rytmu wypróżnien

$\square$ wąskie „ołówkowate" stolc

uczucie niepełnego wypróżnienia

$\square$ ból brzucha, krocza i/lub odbytu

$\square$ zaparcia

$\square$ wzdęcia

nietrzymanie stolca i/lub gazów

$\square$ świąd okolicy odbytu

$\square$ dyskomfort podczas siedzenia

$\square$ uczucie dyskomfortu w jamie brzuszne

$\square$ widoczny lub wyczuwalny guz w okolicy odbytu $\quad$ nudności, wymioty

11. Które z działań według Pana/Pani mogą zapobiec zachorowaniu na raka jelita grubego?

(można zaznaczyć więcej niż jedną odpowiedź)

$\square$ utrzymywanie prawidłowej masy ciała

口 regularna aktywność fizyczna

$\square$ ograniczenie spożycia alkoholu

$\square$ niepalenie tytoniu

$\square$ ograniczenie spożycia czerwonego mięsa

$\square$ stosowanie diety bogatej w błonnik pokarmowy, warzywa, owoce i ryby

$\square$ długotrwałe przyjmowanie niesteroidowych leków przeciwzapalnych, w tym kwasu acetylosalicylowego

$\square$ stosowanie hormonalnej terapii zastępczej u kobiet w okresie pomenopauzalnym

12. Czym według Pana/Pani są badania przesiewowe (badania skriningowe)?

$\square$ to badania wykonywane wśród osób, które zgłaszają objawy danej choroby, w celu potwierdzenia jej rozpoznania

$\square$ to badania profilaktyczne, wykonywane w celu rozpoznania choroby w początkowym, jeszcze bezobjawowym jej stadium; badania te obejmują najczęściej osoby, które posiadają podwyższone ryzyko zachorowania na daną chorobę

$\square$ to badania obejmujące grupy osób z najniższym w populacji ryzykiem zachorowania na określoną chorobę

$\square$ nie wiem 
13. Spośród poniższych badań, proszę wskazać jedno badanie profilaktyczne, które jest według Pana/Pani zalecane i stosowane najczęściej w celu wczesnego wykrycia raka jelita grubego.

(można zaznaczyć maksymalnie jedną odpowiedź)

$\square$ badanie proktologiczne (per rectum)

$\square$ test na obecność krwi utajonej w kale

$\square$ badanie laboratoryjne krwi

$\square$ badanie ultrasonograficzne (USG) jamy brzusznej

$\square$ tomografia komputerowa

$\square$ rezonans magnetyczny

$\square$ badanie kontrastowe jelita grubego (tzw. wlew doodbytniczy)

$\square$ rektoskopia

$\square$ sigmoidoskopia

$\square$ kolonoskopia

$\square$ badanie poziomu antygenu (markera) nowotworowego CEA (ang. carcino-embryonic antygen) w surowicy

$\square$ badania genetyczne $w$ kierunku predyspozycji do wystąpienia raka jelita grubego

14. W jakim wieku według Pana/Pani należy rozpocząć wykonywanie badań profilaktycznych w kierunku raka jelita grubego (w przypadku osób, które nie posiadają objawów choroby ani dodatkowych czynników ryzyka)? $\square$ po 30. roku życia

$\square$ po 40. roku życia

$\square$ po 50. roku życia

$\square$ nie wiem

15. Jak często według Pana/Pani powinno się wykonywać profilaktyczne badanie na obecność krwi utajonej w kale?

$\square$ co roku

$\square$ co 2 lata

$\square$ co 10 lat

$\square$ nie wiem

16. Na czym według Pana/Pani polega badanie kolonoskopowe?

$\square$ to badanie pozwalające na ocenę błony śluzowej odbytnicy i odbytu po uprzednim wykonaniu lewatywy; polega na wprowadzeniu przez odbyt sztywnego wziernika i ocenie końcowego odcinka przewodu pokarmowego $\square$ to badanie umożliwiające zbadanie całego jelita grubego po wcześniejszym przyjęciu środka przeczyszczającego; polega ono na wprowadzeniu przez odbyt cienkiego, giętkiego wziernika zakończonego kamerą i ocenie wnętrza całego jelita grubego

$\square$ to badanie, które polega na wprowadzeniu przez jamę ustną giętkiego aparatu i dokładnej ocenie górnego odcinka przewodu pokarmowego

$\square$ nie wiem

17. Czy słyszał/a Pan/Pani o Programie Badań Przesiewowych raka jelita grubego, w ramach którego wykonywane są bezpłatne profilaktyczne badania kolonoskopowe?

$\square$ tak

$\square$ nie

Jeśli tak, proszę wskazać:

A. Do kogo adresowany jest ten Program?

$\square$ do osób w wieku 50-65 lat, które zgłaszają niepokojące objawy, mogące wskazywać na rozwój procesu chorobowego

$\square$ do wszystkich osób w wieku 50-65 lat bez objawów raka jelita grubego, a także do osób młodszych obciążonych dodatkowym ryzykiem zachorowania (predyspozycje rodzinne/genetyczne)

$\square$ do mężczyzn w wieku 40-70 lat oraz do kobiet w wieku 50-70 lat

$\square$ do osób w wieku 20-59 lat, które nie posiadają objawów raka jelita grubego

$\square$ nie wiem

B. Jak często można wykonywać bezpłatne badania kolonoskopowe w ramach Programu w przypadku przeciętnego ryzyka rozwoju raka jelita grubego?

$\square$ co 3 lata

$\square$ co 5 lat

$\square$ co 10 lat

$\square$ co 15 lat

$\square$ nie wiem 
$\rightarrow$ Jeśli nie ukończyt/a Pan/Pani 50. roku życia prosze przejść do pytania 19.

18. Czy kiedykolwiek skorzystał/a Pan/Pani z bezpłatnego badania kolonoskopowego w ramach Programu Badań Przesiewowych raka jelita grubego?

$\square$ tak

$\square$ nie

Jeśli nie, to z jakiego powodu? (można zaznaczyć więcej niż jedną odpowiedź)

$\square$ lęk przed zdiagnozowaniem choroby

$\square$ krępująca forma badania

口 lęk przed bólem podczas badania

$\square$ brak zaufania do specjalistów

$\square$ ograniczony dostęp do badań diagnostycznych na zamieszkiwanym obszarze

$\square$ brak wiedzy o możliwości skorzystania z bezpłatnego badania w ramach Programu

$\square$ inny (jaki?)

Czy zamierza Pan/Pani zgłosić się na bezpłatne przesiewowe badanie kolonoskopowe?

$\square$ tak

$\square$ nie

19. Któremu z poniżej wymienionych badań kiedykolwiek Pan/Pani się poddał/a?

(można zaznaczyć więcej niż jedną odpowiedź)

$\square$ badanie proktologiczne (per rectum)

$\square$ test na obecność krwi utajonej w kale

$\square$ rektoskopia

$\square$ sigmoidoskopia

$\square$ kolonoskopia

$\square$ badanie poziomu antygenu (markera) nowotworowego CEA (ang. carcino-embryonic antygen) w surowicy

$\square$ badania genetyczne $w$ kierunku predyspozycji do wystąpienia raka jelita grubego

$\square$ nigdy nie poddałam/poddałem się żadnemu z powyższych badań

20. Jak ocenia Pan/Pani poziom własnej wiedzy na temat raka jelita grubego i jego profilaktyki?

$\square$ bardzo niski $\square$ wysoki

$\square$ niski $\quad \square$ bardzo wysoki

$\square$ przeciętny

21. Z jakich źródeł najczęściej uzyskuje Pan/Pani informacje na temat profilaktyki raka jelita grubego? (można zaznaczyć maksymalnie trzy odpowiedzi)

$\square$ Internet

$\square$ telewizja

$\square$ radio

$\square$ lekarz specjalista w dziedzinie

$\square$ ulotki informacyjne

$\square$ fachowe piśmiennictwo medyczne

$\square$ czasopisma

gastroenterologii/chirurgii/onkologii/radiologi

$\square$ pielęgniarka

$\square$ rodzina

口znajomi

$\square$ inne (jakie?)

$\square$ lekarz pierwszego kontaktu

22. Czy chciałby/chciałaby Pan/Pani poszerzyć swoją wiedzę w zakresie profilaktyki raka jelita grubego?

$\square$ zdecydowanie tak

$\square$ raczej tak

$\square$ raczej nie

$\square$ zdecydowanie nie 